Canadian

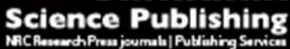

Applied Physiology, Nutrition, and Metabolism Physiologie appliquée, nutrition et métabolisme

\title{
Current Considerations Related to Physiological Differences Between the Sexes and Physical Employment Standards
}

\begin{tabular}{|r|l|}
\hline Journal: & Applied Physiology, Nutrition, and Metabolism \\
\hline Manuscript ID & apnm-2015-0540.R2 \\
\hline Manuscript Type: & Review \\
\hline Date Submitted by the Author: & 01-Feb-2016 \\
\hline Complete List of Authors: & $\begin{array}{l}\text { Roberts, Delia; Selkirk College Castlegar, } \\
\text { Gebhardt, Deborah; Human Performance Systems, Inc } \\
\text { Gaskill, Steven; University of Montana } \\
\text { Roy, Tanja; US Army Public Health Command } \\
\text { Sharp, Marilyn; USARIEM, Military Performance }\end{array}$ \\
\hline Keyword: & $\begin{array}{l}\text { Physical employment standards, selection standards, sex differences, job } \\
\text { task performance, work performance }\end{array}$ \\
\hline &
\end{tabular}

SCHOLARONE ${ }^{\text {m }}$

Manuscripts 


\title{
Current Considerations Related to Physiological Differences Between the Sexes and Physical Employment Standards
}

\author{
Delia Roberts, Deborah L. Gebhardt, Steven E. Gaskill, \\ Tanja C. Roy, and Marilyn A. Sharp
}

Corresponding Author:

Delia Roberts, PhD, FACSM

School of University Arts and Sciences

Selkirk College

$28089^{\text {th }}$ Ave

Castlegar, BC VIN $2 Z 1$

Email: droberts@selkirk.ca

Phone: 2503651820

Fax: 2503656568

Deborah L. Gebhardt, PhD

Human Performance Systems, Inc.

5000 Sunnyside Avenue, Suite 203

Beltsville, MD 20705

Email: dgebhardt@humrro.org

Steven E. Gaskill, PhD

The University of Montana

Health and Human Performance Dept. - Exercise Science

204 McGill Hall

Missoula, MT 59812

Email: Steven.gaskill@umontana.edu

Tanja C. Roy, PhD

Executive Officer, Epidemiology and Disease Surveillance

US Army Public Health Command

Blackhawk Rd

Aberdeen Proving Ground, MD

Email: tanja.c.roy.mil@mail.mil

Marilyn A. Sharp, MS

Military Performance Division

U.S. Army Research Institute of Environmental Medicine

42 General Green Ave

Natick, MA 01760-5007

Email: marilyn.a.sharp.civ@mail.mil 


\section{Abstract}

The use of Physical Employment Standards (PES) has helped ensure that workers have the physical attributes necessary to complete their jobs in a safe and efficient manner. However, PES used in the selection processes have not always reflected the critical physical requirements of the job tasks. Women generally have smaller anthropometric stature than men, less muscle mass and therefore less strength, power, and endurance, particularly in the upper body. Nonetheless, these attributes in themselves are not valid grounds for exclusion from employment in physically demanding occupations. Selection standards based upon size or strength, irrespective of the job requirements, have resulted in the barring of capable women from physically demanding jobs, claims of gender bias, and costly litigations. In order to ensure all individuals are provided with equal access to employment, accurate characterization of the critical physical requirements of the job is paramount.

This paper summarizes the existing research related to disparities between the sexes that contribute to sex differences in job performance in physically demanding occupations including physical and legal factors. Strategies for mitigating these differences in the setting of PES and the meeting of minimum employment standards are discussed. Where available, injury rates for women and men in physically demanding occupations are presented and the etiology considered. Lastly, areas for further research are identified.

Key Words 
Physical employment standards, selection standards, sex differences, job task performance, work performance, occupational injury, physical screening, physical selection. 


\section{Introduction}

Throughout history women have performed tasks involving strenuous physical labour (Barlow et al. 1993). However, as long as fifty years ago, women were considered to be physically incapable of performing hard work and were barred from arduous occupations by cultural and regulatory dictates. Ironically, it may have been the institution of physical employment standards (PES) that inadvertently began to re-open physically demanding occupations to western women. Today, women have equal access to nearly every type of occupation, including many positions that were traditionally held only by men.

The first generation of PES were often based only on data gathered from men (characteristics based standards), and designated as minimum size and physical fitness requirements (U.S. Library of Congress 2005). As the majority of women have smaller anthropometric stature than men, less muscle mass and therefore less physical capacity, these minimum standards were often biased against women without necessarily having the predictive capacity to select for those who could successfully complete the critical physically demanding job tasks. Ensuring that the test design is a true representation of the critical job-related task requirements is essential to eliminating concerns around selection bias.

This paper summarizes existing research related to differences in physical performance between the sexes with a focus on situations where time and environmental constraints may limit the ergonomic options for competing the necessary tasks. Where possible we also include data from a variety of occupations which may not be as critically time sensitive as emergency services, but which still require employees to complete physically demanding jobs in a time-sensitive, safe and efficient manner. We will make 
use of the term "sex differences" as those differences between women and men that are due to biological differences such as physiological or anatomical attributes, while we make use of the term "gender" to indicate those differences that include a cultural aspect that affects the way we interpret these differences.

\section{Employment Laws and Litigation}

Many countries have been strongly influenced by the United States Civil Rights Act of 1964 (CRA 1964), which made it illegal to discriminate on the basis of sex and other factors in the employment setting. Further augmented in 1991 (CRA 1991), the amended act disallowed score adjustments such as separate passing scores for tests based on sex and race. This was of particular note for the use of tests in which the physical differences between men and women can result in adverse impact on women. Thus, the practice of within-group norming to avoid adverse impact of a test could no longer be used.

Another important document is the United States' Uniform Guidelines on Employee Selection Procedures (EEOC 1978). Created as an intra-agency set of guidelines that delineate the requirements for the development of legally defensible selection procedures, the Uniform Guidelines describe how to conduct a job analysis, validate assessment procedures, identify minimum qualification levels, and document the processes. Discrimination is defined in terms of adverse impact by sex, race, or ethnic group using the $4 / 5$ ths or $80 \%$ rule in which the passing rate of one group (e.g., women) is less than $80 \%$ of the group with the highest passing rate (e.g., men). The Uniform Guidelines do not prohibit tests with adverse impact against a protected group as long as those tests comply with technical standards for validity studies (Section 14) and documentation of impact and validity evidence (Section 15) (EEOC 1978). 
In addition to the Uniform Guidelines (EEOC 1978), several professional societies generated documents that also define procedures and standards for establishing the validity of selection procedures and the use of employment assessments. Two prominent documents in this area are the Standards for Educational and Psychological Testing (AERA, APA, NCEME 2014) and the Society of Industrial Organizational Psychology Principles for the Validation and Use of Personnel Selection Procedures (SIOP 2003). They describe the sources and types of evidence needed to establish assessment validity and address the selection of assessment procedures, criterion measure development, data analysis, documentation, and implementation guidelines. These series of guidelines have been adopted in alternate forms by several other countries.

In the United Kingdom, The Equality Act 2010 includes sections that address employment discrimination in relation to sex, race, religion, age, and disability similar to the laws in the United States. The Canadian Human Rights Act (1985) contains clauses that address discriminatory employment practices, whether direct or indirect, prior to and during employment. The act prohibits discrimination based on race, sex, age, ethnic origin, and other categories. Of particular note to this act is the Meiorin Decision that shaped the requirements for establishing PES in Canada, and further, drew international attention. This decision stipulated that when the critical physical demands of the job are performed by multiple subgroups (e.g., men, women), the standard must be based on the subgroup with the lowest test scores that meet the job requirements in terms of safety and efficiency. In contrast, laws governing discrimination are separate in Australia, and address age, racial, sex, and disability (e.g., Age Discrimination Act 2004, Sex Discrimination Act 1984), along with the Australian Human Rights Commission Act 1986. The Human Rights law also includes addition subgroups such as color, religion, marital 
status, and others. Thus, in spite of individual differences in legislation amongst different countries, there are also many similarities.

Litigation in the area of PES testing is predominantly related to adverse impact on women. As women were denied the opportunity to enter higher paying trades and public safety jobs, greater scrutiny was placed on the selection procedures and decision models used by organizations. Physical variances between men and women resulted in differences in selection test scores, in turn creating disparate impact on women. This was recognized as a violation of the $80 \%$ rule, with an adverse impact due to the lower passing rate of women (the protected/minority group) when compared to men (the majority group) (EEOC 1978). Litigation in this area also addressed all aspects of the development and use of PES such as job analysis, test validity, reasonableness of the physical tests, use of less discriminatory alternatives, and critical occupational necessity. For each of these themes, the courts have found for and against the defendant (employer).

Adverse impact against women due to violation of the $80 \%$ rule was the primary trigger for most litigation. PES tests violating the $80 \%$ rule have been upheld in American courts, but only if the validity evidence demonstrated the job relatedness of the test. Cases such as Ernst v City of Chicago (2015) and Lanning v. SEPTA (1999; 2002) demonstrated that validity evidence in the form of validation studies, use of job analysis information, and identification of minimally acceptable standards met the criteria stated in the Uniform Guidelines (1978) and professional guidelines (e.g., SIOP Principles). In both cases, job performance criteria was established and accepted by the court. In Ernst v City of Chicago the court stated that the job analysis and validation study were appropriate 
and that the test was related to the paramedic job and consistent with critical occupational necessity. In contrast, the courts ruled against the defendant in cases in which the job analysis was weak and the validation of the test did not meet published standards (United States v. City of Erie 2005, Legault v. Russo 1994).

The passing score(s) on PES are set during the validation process. However, the passing scores must reflect minimum job requirements and/or critical occupational necessity. The court upheld the PES tests and passing scores when the defendant demonstrated the relationship between job performance and PES test performance (Ernst v City of Chicago 2015; Lanning v. SEPTA 1999; 2002, Smith v. Des Moines 1996). For instance, the court found that an aerobic power of $42 \mathrm{~mL} \cdot \mathrm{kg}^{-1} \cdot \mathrm{min}^{-1}$ was required for an officer to run from one train station to another in an emergency (Lanning v. SEPTA 1999; 2002). Conversely, the courts found for the plaintiff when the passing score was not related to minimum acceptable job performance or was subjective in nature (EEOC v. Dial Corp 2006; United States v. City of Erie 2005). In the Dial case, a subjectively scored PES test resulting in a decline in the female selection rate (48\% to $8 \%$ ) was deemed more difficult than the requirements of the job. Further, the defendant was unable to demonstrate their critical occupational necessity defense that the PES test lowered injuries.

The plaintiff also prevailed in the Canadian landmark case, known as the Meriorin decision, due to the defendant's inability to demonstrate critical occupational necessity and job requirements (British Columbia (Public Service 24 Employee Relations Commission v British Columbia Government and Service Employees' Union 25 (B.C.G.S.E.U.) (Meiorin Grievance) [1999] 3 SCR 3 [Meiorin 1999]). In finding for the 
plaintiff, the Supreme Court of Canada put forth a three-part test for assessing whether a standard is discriminatory (i.e., standard has rationale relation to job, is necessary, and is in good faith). A more detailed description of this litigation and others is found in Adams (2015).

The issue of separate male-female passing scores has had mixed results in litigation, with most of the recent cases embracing a single passing scores for PES (Bauer v. Holder. 2014, Easterling v. State of Connecticut Department of Correction 2011). In Bauer v. Holder, the court found that the Federal Bureau of Investigation's (FBI) training academy physical test with sex normed passing scores resulted in disparate treatment towards men. The physical test for selection of correction officers was found to have disparate impact on women, even though sex normed passing scores were used. These court decisions and others emphasize the importance of defining the minimum level of job performance via job analysis and validity studies.

Finally, case law also addressed the efficacy of test components in both basic ability and job simulation tests (e.g., Hardy v. Stumpf 1978). The courts upheld the defendants' physical tests when a link between the test component and job requirements was present (Hardy v. Stumpf 1978; Ernst v City of Chicago 2015). In one case the court found that climbing over a fence was a reasonable task required of police officers (Hardy v. Stumpf 1978).

Each of these cases has helped to encourage the precise definition of procedures and standards for establishing valid PES that accurately reflect the physical capacities required to perform critical job tasks in a safe and efficient manner. Thus, they have also helped to reduce sex bias for employment in physically demanding jobs. 


\section{Physical Sex Differences and Implications for Occupational Performance}

The differences in physical constructs between the sexes that pertain to job performance during physically demanding tasks include body size and composition, muscular strength and endurance, aerobic power and anaerobic power. A brief synopsis of these differences follows; however, a more in-depth review of sex based physiological differences can be found elsewhere (Epstein et al. 2013).

Body Size and Composition: Although body size and composition do not always correlate with job performance, they have a significant impact on an individual's physical attributes. These measures are also important to consider as they (especially body size) were widely used as defining metrics in the early days of PES.

In general, men are taller $(8 \%)$, weigh more $(26 \%)$, and have less body fat (about $10 \%$ less essential fat) than women (Gordon et al. 1988; Malina et al. 1991). In addition, men have $50 \%$ and $30 \%$ more lean mass than women in their arms and legs, respectively (Miller et al. 1993). Thus, the relative proportions of lean muscle mass and fat mass, as well as the distribution of muscle are different for men and women, and this can have profound effects on physical capacities irrespective of fitness level. It is important to note however, that although stature is often associated with physical capacities, size does not predict safe and efficient critical job-related task performance, and the use of body dimensions is not a legally defensible means of setting PES (Jackson 1994). In spite of this there remain some instances where a body dimension is a bona fide occupational 
requirement, such as the need to fit into a small space, or sufficient reach to operate a control.

Muscular Strength, Power and Endurance: Women have approximately $70-75 \%$ of the lower body strength and $40-60 \%$ of the upper body strength than that of men, with the ratio being influenced by metric used, age and state of training (Wilmore et al. 2008). Although the average man is stronger than the average woman, there is an overlap in strength, and the strongest women are as strong or stronger than the lowest strength men (Sharp 1994). Figure $1 \mathrm{~b}$ illustrates this distribution, as well as the narrowing of the sex-based strength gap when data are normalized for muscle mass (Fig 1c) (reproduced by permission, Sharp 1994).

The ability to maintain a specific level of force or power output over repeated contractions at low intensities is greater for women than for men, however, as the intensity reaches $80 \%$ or more of the individuals' maximum, no sex-based differences in muscular endurance are seen (Wilmore et al. 2008; Hicks et al. 2001). In occupations like reforestation work, the ability of women to perform equally as well as men at moderate intensity tasks over extremely long durations is evident (Roberts 2009). This is a significant effect as work tasks are rarely assigned relative to maximal strength, but rather are generally fixed by an absolute external load. In practice, absolute muscular endurance or the ability to move objects of a set weight (e.g. carrying a casualty, lifting a box) is more reflective of job task performance than measures of endurance relative to an individual maximum.

Given her smaller size and strength, the average woman must use a greater percentage of her capacity to move the same object than the average man, and unless 
she has a higher level of submaximal muscular endurance, she is more likely to become fatigued more quickly. To adequately perform a task requiring repeated heavy lifting, workers must be strong enough that the given absolute workload is a sustainable, submaximal proportion of their maximal lifting strength. Savage et al. (2014) created a model to estimate the maximal box lifting strength needed to ensure an individual is capable of performing a given number of repetitions. Although the model was based on a single lifting task and is used to predict a range of repetitions, it provides some guidance in setting minimum strength standards for repetitive lifting tasks.

Anaerobic power is important for tasks that may need to be performed by first responders in an emergency, or by the military under fire, such as sprinting while carrying a heavy load or quickly dragging a casualty from danger. Values for upper and lower body maximum anaerobic power in women are reported to be $37 \%$ (Nindl et al. 1995) and $60-70 \%$ (Yanovich et al. 2008) respectively, of those reported for men, which may impact the ability of women to successfully complete tasks requiring rapid application of maximal levels of force. Very little research has been reported in this area.

Aerobic Power: In general, moderately trained women have $\mathrm{VO}_{2}$ max levels that are $15-30 \%$ lower than moderately trained men in absolute (liters $\bullet \mathrm{min}^{-1}$ ) and about $10 \%$ lower in relative $\left(\mathrm{mL} \cdot \mathrm{kg}^{-1} \cdot \mathrm{min}^{-1}\right)$ terms (Vogel et al. 1986). However, sustained submaximal output may be more important than $\mathrm{VO}_{2}$ max for work performance, and this metric can be evaluated during work tasks or estimated from the ventilatory threshold in a laboratory setting (Gaskill et al. 2001a). Although men wildland firefighters tended to have a higher $\mathrm{VO}_{2}$ max than women wildland firefighters, they had comparable absolute ventilatory thresholds. When wildland firefighters performed various tasks in laboratory and field 
settings, the highest steady state oxygen consumption values recorded were during long uphill hikes. In practice, all individuals on a crew hike together as a team and carry the same equipment. Thus, in order to meet this performance criterion, women were sustaining a higher work-intensity (approximately $80 \% \mathrm{VO}_{2} \mathrm{max}$ ). This finding supports the observation that when highly trained, women are capable of performing the same arduous jobs as men.

Clearly, the sex differences discussed above for strength and endurance are important to performance of sustained tasks such as repetitive lifting or extended load carriage. The impact of a high $\mathrm{VO}_{2}$ max on repetitive performance of physically demanding tasks suggests that the use of minimum required standards for $\mathrm{VO}_{2}$ max may be an acceptable assessment metric for PES, if the aerobic requirements of the job are accurately defined. However, sustained performance at an absolute submaximal level may be a more specific measure of critical job task performance.

Physical Training to Improve Performance in Physically Demanding Jobs.

Appropriate physical training has been used to improve performance during physically demanding job tasks in both men and women (Harman et al. 1997). Generalized training based on non-specific exercises such as running or lifting weights, has the potential to improve performance of a wide variety of tasks. In contrast, task specific physical training utilizes the job tasks to induce the training response and tends to produce larger improvements of a single task, such as pulling a charged fire hose (Knapik et al. 1998). Practicing to perform PES tests can also be considered a type of task specific training 
and has been used as a strategy for PES test preparation. Familiarization with the PES testing procedures, as well as a six week progressive job-task specific resistance and aerobic conditioning program, have both been shown to be effective in improving PES scores and passing rates in women (Jamnik et al. 2010b).

Aerobic training has been shown to result in improved performance in occupations with a high aerobic demand such as tree-planters (Roberts 2009), wildland firefighters (Sharkey et al. 2009) and soldiers (Knapik et al. 1996; Kraemer 2004). Gaskill et al. (2001b) demonstrated large gains in submaximal aerobic fitness with training at the ventilatory threshold. This may provide an advantageous training strategy for women, as they generally must perform at a higher proportion of $\mathrm{VO}_{2}$ max than the average man in order to sustain the same fixed work output.

A number of studies have shown that combined resistance and aerobic training programs can be used to improve the performance of women at physically demanding occupations. A recent review of the programs used to improve women's performance of military occupational tasks concluded that a minimum of six-months training using jobtask specific exercises for load carriage, with an emphasis on upper body strength and power were necessary to prepare women for combat occupations (Nindl 2015). Kraemer (2001b) also found a six month combined training program improved the repetitive lifting and load carriage performance of women such that there was no sex difference when compared to untrained men. Manual materials handling performance in both men and women is increased by approximately 5 to $35 \%$ depending on the type of task, as well as the specific exercises, duration and intensity of the training program (Knapik et al. 1996; Harman et al. 2008). Similar gains with shorter duration training programs have also been 
reported for tree-planters, where a combined program of movement specific resistance exercises and generalized cardiovascular training resulted in an observed $12 \%$ increase in mean daily production following eight weeks of training (Roberts 2009). Similarly, a seven-week task specific program consisting of hikes with progressively heavier packs and select resistance training exercises reduced hiking times in firefighters by $17 \%$ and increased line digging distance by $14 \%$ (Sharkey et al. 2009).

These studies illustrate the effectiveness of an appropriate program of physical training for women in preparation for PES testing, as well as to maintain the required level of physical fitness to perform the critical job tasks in a safe and efficient manner over time. Women in physically demanding occupations are often required to perform at a higher percentage of their maximal physical ability to perform job related tasks (Gaskill et al. 2009), however, the data suggest that many women, are able to increase fitness to meet these job demands. The consequence however, is that women may have a reduced reserve above normal work conditions to respond to emergencies.

Not all physical jobs require physically demanding activity on a daily basis, thus deconditioning resulting in poor job performance may occur. Such a decline in fitness may be critical for women given that it can place them at a higher risk of not being able to sustain enough fitness to meet the job requirements than for men (or larger individuals) with inherent higher work capacities. To prevent this, employers should provide the resources for employees to maintain the level of fitness required for the job. However, even when the employer does not have the resources to provide time and equipment for training, employees may need to execute physical training under their own auspices. This 
will enable them to maintain their fitness levels such that they can continue to perform the critical job tasks in a safe and efficient manner over time.

Sex Differences in Musculoskeletal Injury (MSI) in Physically Demanding Occupations

Many studies on musculoskeletal injuries have been conducted in the military, with the majority-taking place in the controlled environment of basic training. Amongst these studies, there is a consensus that the incidence of injury in recruits and service members is higher for women compared to men, with $45 \%$ to $57 \%$ of women and $27 \%$ to $46 \%$ of men respectively, sustaining a musculoskeletal injury (MSI) during initial military training (Almeida et al. 1999; Bell et al. 2008).

Professional service women (service members who have already completed their initial training and are serving in regular military units) continue to experience more injuries than men both in simulated military operations ( $10 \%$ of men and $23 \%$ of women) (Darakjy et al. 2003) and during active deployment (22\% of men and $39 \%$ of women) (Roy et al. 2015b). Although physical training, mechanical work, and airborne activity were ranked as the leading causes of injury for both sexes, road marching and garrison activities produced the most injuries in women (Knapik et al. 2007). Additionally, some jobs (wheeled vehicle mechanics, signal intelligence analysts and voice interceptors) have been identified as having higher rates of discharge for women than for men (Feuerstein 1997).

Differences were also found in the types of injuries experienced, with women reporting more lower-extremity injuries and men reporting more back injuries (Billings 2004; Roy et 
al. 2015b). Furthermore, in a study investigating lower extremity injuries, women were found to experience predominately patellofemoral pain syndrome, whereas men suffered mostly illiotibial band syndrome (Almeida et al. 1999).

In the private sector, studies with factory workers have also indicated a higher prevalence of upper body injuries for women than for men (Nordander et al. 2008). In contrast, a study with tree-planters indicated that women were working at significantly higher intensities and had nearly twice the stress hormone levels than men, yet the amount of medical aid and lost time injuries in women was proportionally the same as that of men. Women were, however, $20 \%$ more likely to take a day or two of reduced duty after reporting to first aid (Roberts 2004). Similarly, a study of wildland firefighters (20032007) found women's injury rates were only slightly higher than those for men with no significant differences by injury type (Britton et al. 2013).

Women tree-planters and firefighters have both been measured with $\mathrm{VO}_{2}$ max levels approaching those of highly trained athletes (Gaskill et al. 2009; Roberts 2009). It may be that the high levels of cardiovascular fitness helps to reduce sex based differences in injury rates. Several researchers have concluded that sex is an independent factor in predicting injury rates (George et al. 2012; Strowbridge 2005), but when corrected for fitness this relationship no longer holds true (Bell et al. 2000; Blacker et al. 2008; Knapik et al. 2011a).

Unfortunately, these observational studies do not fully explain why certain activities place women at an increased risk of injury compared to men. Research with athletes has shown that specific movement patterns commonly seen in women can place them at greater risk for patellofemoral pain (Myer et al. 2014), as well as anterior cruciate 
ligament tears (Hewett et al. 2010). Etiologies attributed to sex differences in injury risk include muscle strength, $Q$ angle in the knee, smaller notch size in the femur, movement patterns, joint laxity, and ligament size (Gwinn et al. 2000; Agel et al. 2005; Hewett et al. 2006). Anatomical differences in bone structure (narrower long bones with thinner cortices) between men and women may also lead to the higher incidence of stress fractures seen in women Army and Marine recruits (Beck et al., 2000; Gam et al., 2005; Jones et al. 1993). Interventions such as reducing the running mileage in training decreased the number of injuries in women soldiers by over $10 \%$ and stress fractures by $54 \%$ with no reduction in running speed (Knapik et al. 2005). Providing calcium with vitamin $\mathrm{D}$ supplements has also been shown to be effective in reducing the number of stress fractures in female Naval recruits by $20 \%$ (Lappe et al., 2008).

Hewett et al. (2006), have shown that simple proprioceptive exercises to improve lumbar and hip control by women athletes are extremely effective as part of an injury prevention program. This has also been found in the workplace (Roberts 2013), suggesting that correcting poor movement patterns can provide some protection against injuries in physically demanding occupations. In addition to corrective exercises for those employed, pre-employment functional movement assessments may hold promise for reducing injuries in the workplace (Teyhen et al. 2014).

\section{Considerations Regarding Equipment}

Many physically demanding jobs involve the use of specialized equipment that can add significantly to the workload. Military personnel and wildland firefighters are routinely required to lift or carry loads in the $40 \mathrm{~kg}$ range (Sharp et al. 1994; Gebhardt et al. 2011), 
and personal protective equipment can double this weight (Roy et al. 2015a). Due to the lower work capacities of women, the relative increase in physical demand with these kinds of loads may be more debilitating for women than it is for men (Murphy et al. 2001).

In addition to equipment that is bulky or heavy, there are many other types of specialized equipment that may not fit women very well due to anthropometric differences between men and women. For the most part, equipment manufacturers have been slow to consider the need to customize sizing for women's frames. This creates disparate effects as poorly fitting equipment can significantly contribute to the mental and physical demands of a task and may increase the risk of injury (Murphy et al. 2001; Knapik et al. 2004). The US Army and commercial manufacturers have redesigned body armor to better fit women by accommodating narrower shoulders, shorter torsos and breast tissue. These modifications have resulted in an increased range of movement in the arms, reduced chafing at the hips while walking, and an improved ability to seat a weapon while firing (Leipold 2012).

Workers themselves have also been able to modify their equipment. Women smoke jumpers designed a chainsaw hip-pivot support for use during sawyer work and developed more efficient carriage systems for their $45 \mathrm{~kg}$ pack-out packs to enable them to better perform their jobs (Gaskill-unpublished).

\section{Sex Differences in Response to Environmental Extremes}

Physically demanding occupations are often performed under harsh environmental conditions such as extremes of heat and cold, underwater or at high altitude. Thus, if of a 
large enough magnitude, sex-based differences in the response to extreme environmental conditions could contribute to differences in job performance.

The differential effects of heat and cold on the sexes are discussed elsewhere in a comprehensive review by Epstein et al. (2013). Briefly, women are less capable of dissipating excess heat when performing physical work in a hot environment, due to higher body fat and lower sweat rates than men. For the same job task, women will show a greater increase in heat load (Gagnon et al. 2009). It has also been suggested that this effect may be slightly exacerbated during the luteal phase of the menstrual cycle due to hormonal fluctuations affecting central thermoregulatory centers (Inoue et al. 2005). Whether the hormonal induced alteration in response to sensitivity to heat load is large enough to impact the performance of motivated women in the field is unkown. McLellan (1998) studied women and men performing mild exercise while wearing vapor resistant protective clothing. On average women accumulated heat faster and had a shorter tolerance time than men. However, when subjects were matched for body composition the differences disappeared, confirming that the higher levels of body fat generally seen in women can reduce their ability to work under conditions of external heat load.

Repeated exposure to heat leads to adaptations that can mitigate at least some of the reduction in work capacity and risk of heat illness that occur with rising core temperatures (reviewed by Taylor 2014). Thus, acclimation may be critical for women to maintain their performance at physically demanding tasks in hot environments.

In contrast, when faced with retaining heat in cold environments, the higher body fat generally seen in women should be advantageous. This effect may be counterbalanced by the increased surface area to volume ratio seen in individuals of smaller stature as 
when matched for body size and composition, men and women lose heat at similar rates (Tikuisis et al. 2000). Women, however, did perform significantly better than men at both physical and mental tasks when body temperature was lowered (Solianik et al. 2014). Only men displayed a reduction in muscle force generation, and the impairment of performance for a cognitive task was greater in men than in women. One aspect of performance in the cold that has been shown to be more problematic for women than for men, and may be of particular consideration for tasks that preclude the use of bulky insulating gloves, is the increased incidence of Raynaud phenomenon in women over men (reviewed in Flavahan 2015). Research indicates that the effect is highest during the mid-luteal phase of the menstrual cycle, correlates with serum levels of $17 \beta$-oestradiol, and is related to hormonal induced alterations in the sensitivity of the vasculature of the extremities to cold. The resultant vasoconstriction may predispose women to cold injuries of the extremities during the luteal phase of the menstrual cycle. (Flavahan 2015)

One might also expect that women would have greater susceptibility to the effects of hypoxia given their lower oxygen carrying capacity. However, it appears that there are no sex differences in the rate of acclimation to altitude, the prevalence of acute mountain sickness (AMS), or in the ability to perform work while at altitude (Gore et al. 1997; Hackett et al. 1976). Using modeling methods applied to historical data, lower severity but not frequency of AMS were predicted for both active and inactive men than for comparably fit women (Beidleman et al. 2013). The authors hypothesized that the reduced severity of AMS was possibly due to increased progesterone in premenopausal women with possible mediators of endothelial permeability and free radical production. 


\section{Sex Differences in Aging in Physically Demanding Occupations}

The decline in physical capacities seen with aging has implications for strenuous job performance. Cross-sectional studies have shown that $\mathrm{VO}_{2} \mathrm{max}$ decreases at a rate of approximately $1 \%$ per year in healthy sedentary men and women, beginning around 30 years of age (Vogel et al. 1986; Pimentel et al. 2003). Lindle et al., (1997) examined age and sex differences in muscle strength and found both men and women lose strength at a similar rate $(8-10 \%$ per decade) starting around the age of 40 years. Based on past practice, this normal age-related decline physical capacities may be more problematic for women than for men because on average women enter the workforce with lower physical fitness levels. Furthermore, because work tasks are based on absolute loads, the average woman will have to perform at a higher intensity than the average man, and thus, she will require a higher level of submaximal fitness to sustain such a load. The paradox is that this higher workload can in itself provide the training stimulus to maintain her fitness level, whereas the lower relative intensity may result in detraining of the men who are working at a lower percentage of their maximum while performing the same tasks.

When looking at sex differences with aging in physically demanding occupations, one area suggests a difference with important implications. Heart attacks during fitness testing and on the job accounted for 4.9 fatalities/year from 1999-2006 in U.S. wildland firefighting. Of this number, none were women and most were volunteer firefighters, who are generally older, with lower physical capacities than professional firefighters (Sharkey 2008). It must be noted, however, that at the time that these data were gathered, only 
$3.7 \%$ of firefighters were women (Hulett et al. 2008) and this low level of representation may have biased these findings.

These studies suggest that while a younger individual may be able to meet a PES upon entry to a job field, they may not be able to continue to meet that standard over the course of their career. The lower strength and endurance of the average woman may result in the inability to perform at the minimum standard at a younger age than the average man. However, physical training to maintain fitness can reduce age related declines in aerobic power by $40 \%$ in both men and women (Ogawa et al. 1992) as well as prevent the loss of muscle mass and strength with aging in both men and women (Leenders et al. 2013).

\section{Sex Based Differences in Job Task Performance}

In light of the differences in physical work capacity between men and women, it is important to determine if these sex differences have significant effects on job task performance when establishing PES. Two main types of assessments are typically utilized, basic fitness component tests and job task simulations. Basic fitness component tests evaluate the physical constructs required to perform a specific job and include tests of muscular strength, power and endurance, aerobic power, balance, agility, or anaerobic power. In contrast, task simulation or work sample tests, assess the applicant's ability to perform the critical physically demanding job tasks associated with a particular job. Tables 1-4 illustrate the differences between sexes for basic fitness component tests and work sample tests for a number of occupations, grouped by body part, test and test 
category. The performance ratio for women to men is expressed as a percentage $(\mathrm{W} / \mathrm{M} \mathrm{x}$ $100)$, and is used to represent the sex difference in performance. If a lower score represents a better performance, as in run time, the ratio was calculated as M/W $\times 100$. Where there was more than one sample with the same measurement (i.e., sit-ups), a weighted mean was calculated for each sex and W/M ratio was based on the weighted means. In these cases, the range of individual W/M ratio was also reported.

A number of observations can be made upon examination of Tables 1-4. Firstly, sex differences within a test were found to be surprisingly stable, even across different occupations including emergency vs. non-emergency workers. While men typically outperform women in physical ability tests, the degree of the deficit can be influenced by the body part being measured. Sex differences in upper body strength (Tables 1) tend to be greater than in lower body strength (Table 2), and both tend to be greater than differences in abdominal strength (Table 3). Where there are no sex differences in muscle distribution (as in the abdominal musculature) men and women perform equally well as demonstrated by the average performance ratio of $98 \%$ for the sit up test (Table 3). The methodology used for the test is also important. For example, when an external load was added to a sit-up test, women performed only $71 \%$ as many weighted sit-ups in 30 seconds as did men (Reilly et al. 1979). In contrast, women tend to perform better than men for metrics such as flexibility (Table 2).

In examining these tables, it also becomes evident that there are some similarities between performance in the basic fitness component tests and performance in the task simulation tests. For example, women law enforcement officers have been shown to have $56-65 \%$ of the handgrip strength of men, (Table 1), when measured by hand 
dynamometer (Reilly et al. 1979; Arvey et al. 1992; Gebhardt et al. 2012). A comparable task simulation test for correctional officers, (Table 1), showed that women officers used $66 \%$ as much force as men when controlling inmates via wrist holds (Jamnik et al. 2010c). Despite the women officers using less force, these performances were still considered to be safe and efficient.

Task simulation tests are well accepted by work forces, job candidates, and in legal settings due to their face validity. However, basic fitness component tests are often less expensive, easier to implement, and may require less task familiarization to achieve accurate results. Using meta-analytic techniques Courtright et al. (2013) reported that there were greater sex differences for job simulation tests than for basic fitness component tests of overall muscular strength and cardiovascular endurance. A subsequent analysis of selection systems (considering all the tests included in a testing procedure) revealed little difference in actual practice between the two types of testing systems. In view of this finding, the researchers concluded that a system of basic fitness component tests would have similar sex differences to a system of job task simulations. The examples presented in Tables 1-4 indicate that both types of tests are widely used, but sex differences in basic physical abilities and body composition will still be apparent regardless of the type of test administered. The critical issue is to ensure that the minimal acceptable job standard is accurate.

Future Directions and Best Practices 
A variety of approaches have been used to provide fair access of women to physically demanding occupations. These best practices are highlighted below, along with suggestions for future research:

1. Identification of Valid Standards for Physical Jobs. Setting valid PES that reflect the true demands of a job will help to provide qualified women with equal access to physically demanding occupations. Evidence suggests both basic fitness component tests and work sample tests can be utilized with equal effectiveness, but this needs to be established for each work task and occupation. Validation studies should include samples of both men and women to ensure data from individuals of differing sizes are included in setting critical job measures.

\section{Future Research:}

- Where PES are derived from data gathered exclusively from men, new standards and criterion levels should be set based upon data collected from the safe and efficient performance of critical job tasks by incumbent subgroups of both men and women.

- Further research into the use of work at the ventilatory threshold is needed to determine if this is a more effective metric to assess women's ability to complete aerobically demanding tasks than $\mathrm{VO}_{2} \max$.

- The impact of sex differences in anaerobic power on first responder job task performance is largely unexplored.

\section{Standardization of Testing Procedures. Assessment procedures must be} standardized so that women and men are treated equally. The inclusion of opportunities for familiarization trials can have a large effect on performance outcomes of job task 
simulations in particular, but their use must be consistent. It is also important to address any environmental conditions that may affect performance as well as any equipment that is worn or used during the assessments. Personal protective equipment must be properly fitted including load-bearing devices (e.g. protective vests, packs, belts and holsters), as well as specialized footwear (e.g., firefighter boots) and head mounted equipment (helmet, eyewear, masks etc).

\section{Future Research:}

- The reliability of the testing procedures must be established for both sexes to determine the required number of practices needed before a stable score is obtained. Access to testing equipment must be provided to allow for the required number of practices.

\section{Pre-employment Physical Training Programs. The use of pre-employment} physical training programs can help mitigate sex differences in passing PES. These programs should provide applicants with quality training information with the design of the exercises based on critical job tasks and the physical selection assessment.

\section{Future Research:}

- Physically demanding jobs are not in themselves sufficient motivation for workers to maintain their physical capacities with aging or when the demanding job tasks are intermittent. More work is needed to design maintenance training programs that are sustainable and can generate good compliance. 
4. Consider the Impact of Environmental Exposures. If the work is to be performed under extreme environmental conditions, provide guidelines for acclimatization procedures.

Future Research:

- Risk factors for individual susceptibility to heat stress and altitude sickness remain largely unexplained. In addition, sex-based differences in work performance under extremes of cold and hyperbaria are unknown.

\section{Other Areas for Future Research:}

- Much of the published research regarding the setting of PES has been performed with the military and safety-related emergency occupations. Greater efforts should be made to examine the impact of sex on the many other industries where women are required to perform physically demanding work.

- Further research is needed to better understand the risk factors for sex differences in injury rates when training for and performing critical physically demanding job tasks; and to evaluate the use of PES to mitigate these risks. Sex differences in variables such as job attrition, lost time due to injury, injury type and causation, medical expenses and individual productivity, should be monitored and normalized for fitness level and representation by women. Although utility analyses that address these variables and the cost savings of physical testing have been completed, sex differences have only rarely been considered.

- Strategies to prevent injuries in women entering physically demanding jobs such as functional movement assessments and remedial training programs must be 
developed and monitored for effectiveness. These strategies will likely benefit men as well as aging incumbents.

- Very little research is available on the psychological profile of women who are successful at physically strenuous occupations. Better understanding key attributes such as motivation may help to reveal why some women perform well at physically demanding jobs in spite of their smaller size.

- More work on the design of equipment is also needed. While completion of the criterion task needs to be equal for men and women, it may be that ergonomic tools specific to the woman's frame could help to decrease disparate effects.

\section{Conclusions}

A number of anthropometric and physiological differences between women and men that influence physical work capacity have been discussed. These attributes result in many women having lower physical work capacities, and may result in women working at a higher percentage of their maximal capacity than men performing the same job tasks. This higher relative work may place women at higher risk for injury when performing physically demanding tasks. However, a careful study of the body of research examining physical work performance also indicates that many of the differences in task performance between men and women are due to body size rather than sex, and some women are fully capable of performing many physically demanding occupations. Because of the generally smaller female body size and the anatomical differences in the upper body in particular, there will remain a lower percentage of women in many tasks that require either high aerobic or muscular fitness standards. This may be especially true in 
emergency occupations as was recently reported by Ash Carter (U.S. Secretary of Defense) when discussing the opening of all combat positions to women (White House briefing, 12-03-2015). Careful selection procedures and specific physical training for demanding tasks can help qualified women perform safely and efficiently alongside their male colleagues.

\section{Acknowledgements}

The authors wish to thank Joe Domitrovich and Michael Spivock for sharing their research data, Stephen Foulis and Alex Borges for their technical assistance and Stewart Petersen for his editorial guidance.

The authors declare that there are no conflicts of interest

\section{References}

Adams, E. M. 2015. Human rights at work: Physical employment standards and human rights law. Journal of Applied Physiology Nutrition and Metabolism (submitted).

Age Discrimination Act 2004 (No.68, 2004). [Australia]

Agel, J., Arendt, E.A., and Bershadsky, B. 2005. Anterior cruciate ligament injury in national collegiate athletic association basketball and soccer: a 13-year review. Am. J. Sport. Med. 33: 524-530. 
Almeida, S.A., Williams, K.M., Shaffer, R.A., and Brodine, S.K. 1999. Epidemiological patterns of musculoskeletal injuries and physical training. Med. Sci. Sports. Exerc. 31: 1176-1182.

American Educational Research Association (AERA), American Psychological Association (APA), and the National Council on Measurement in Education (NCEME). 2014. Standards for educational and psychological testing. Washington, DC: AERA Publications.

Arnold, J.D., Rauschenberger, J.M., Soubel, W.G., and Guion, R.M. 1982. Validation and utility of a strength test for selecting steelworkers. J.Appl. Psychol. 67: 588-604.

Arvey, R.D., Landon, T.E., Nutting, S.M., and Maxwell, S.E. 1992. Development of physical ability tests for police officers: a construct validation approach. J. Appl. Psychol. 77: 996-1009.

Australian Human Rights Commission Act 1986 (Act no. 125, 1986 as amended).

Bauer v. Holder. 2014. F. Supp. 1:13-cv-00093 (E.D.Va. June 10, 2014).

Beck, T, Ruff, C.B., Mourtada, F.A., Shaffer, R.A., Maxwell-Williams, K., Kao, G.L., Sartoris, D.J., and Brodine, S. 1996. DXA derived structural geometry for stress fracture prediction in male U.S. Marine Corps recruits. J Bone Miner Res, 11: 645-653.

Beidleman, B.A., Tighiouart, H., Schmid, C.H., Fulco, C.S., and Muza, S.R. 2013.

Predictive models of acute mountain sickness after rapid ascent to various altitudes. Med. Sci. Sports. Exerc. 45: 792-800. 
Bell, N.S., Mangione, T.W., Hemenway, D., Amoroso, P.J., and Jones, B.H. 2000. High injury rates among female army trainees: a function of gender? Am. J. Prev. Med. 18: 141-6.

Bell, N.S., Schwartz, C.E., Harford, T., Hollander, I.E., and Amoroso, P.J. 2008. The changing profile of disability in the U.S. Army: 1981-2005. Disabil. Health. J. 1: 14-24.

Billings, C.E. 2004. Epidemiology of injuries and illnesses during the United States Air Force Academy 2002 Basic Cadet Training program: documenting the need for prevention. Mil. Med. 169: 664-670.

Blacker, S.D., Wilkinson, D.M., Bilzon, J.L., and Rayson, M.P. 2008. Risk factors for training injuries among British Army recruits. Mil. Med. 173: 278-286.

Blakley, B.R., Quiñones, M.A., Crawford, M.S., and Jago, I. 1994. The validity of isometric strength tests. Pers. Psychol. 47: 247-274.

Boyce,R.W., Ciulla,S., Jones, G.R., Boone,E.L., Elliott,S.M. and Combs, C.S. 2008. Physical fitness comparison of the Chorlotte-Mecklenburg fire and police departments. Int J Exerc Sci. 1: 125-135.

British Columbia (Public Service Employee Relations Commission v British Columbia 797 Government and Service Employees' Union (B.C.G.S.E.U.) (Meiorin Grievance) 1999. 3 SCR 3798 (Respondent's Amended Factum File No. 26274).

Britton, C., Ramirez, M., Lynch, C.F., Torner, J., and Peek-Asa, C. 2013. Risk of injury by job assignment among federal wildland firefighters, United States, 2003-2007. Int. J. Occup. Environ. Health. 19: 77-84. 
Canadian Human Rights Act (R.S.C., 1985, c. H-6).

Civil Rights Act of 1964 (CRA). 1964. (Title VII), 42 U.S.C. §2000e-2, et seq. (United States).

Civil Rights Act of 1991 (CRA). 1991. 42 U.S.C. § 1981a, et seq. (United States).

Courtright, S.H., McCormick, B.W., Postlethwaite, B.E., Reeves, C.J., and Mount, M.K. 2013. A meta-analysis of sex differences in physical ability: revised estimates and strategies for reducing differences in selection contexts. J. Appl. Psychol. 98: 623-41.

Darakjy, S., Hauret, K.G., Canada, S.E., Knapik, J.J., Hoedebecke, E.L., Wells, J., Kenyon, M., Marin, R.E., and Bullock, S.H. 2003. Injuries and injury risk factors among Armor Battalion soldiers at Fort Riley, Kansas. Med. Sci. Sports. Exerc.. 35: S278.

Drain, J.R., Sampson, J.A., Billing, D.C. Burley, S.D., Linnane, D.M., and Groeller, H. 2015. The effectiveness of basic military training to improve functional lifting strength in new recruits. J. Strength Cond. Res. 29: 173-177.

Easterling v. State of Connecticut, D.o.C. 2011. 783 F. Supp. 2d 323 (D. Conn.).

Epstein, Y., Yanovich, R., Moran, D.S., and Heled, Y. 2013. Physiological employment standards IV: integration of women in combat units physiological and medical considerations. Eur. J. Appl. Physiol. and Occup. Physiol. 113: 2673-2690.

Equal Employment Opportunity Commission, (EEOC). 1978. Uniform guidelines on employee selection procedures. Fed. Regist. 43: 38295-38309. 
Equal Employment Opportunity Commission v. Dial Corp. 2006. No. 05-4183/4311 (8th Cir.).

Feuerstein, M. 1997. Musculoskeletal-related disability in U.S. Army Personnel:

prevalence, gender, and military occupational specialties. J. Occup. Environ. Med. 39: 68-78.

Flavahan, N.A. 2015. A vascular mechanistic approach to understanding Raynaud phenomenon. Nat. Rev. Rheumatol. 11: 146-158.

Foulis,S.A., Redmond,J.E., Warr,B.J., Zambraski,E.J., Frykman, P.N., Sharp, M.A. 2015. Development of the occupational physical assessment test (OPAT) for combat arms soldiers. USARIEM Technical Report, pp1-74, T16-2.

Gagnon, D., Dorman, L.E., Jay, O., Hardcastle, S., and Kenny, G.P. 2009. Core temperature differences between males and females during intermittent exercise: physical considerations. Eur. J.Appl. Physiol. 105: 453-461.

Gam, A., Goldstein, L., Karmon, Y., Mintser, I., Grotto, I., Guri, A.,Bar-Dayan, Y. 2005. Comparison of stress fractures of male and female recruits during basic training in the Israeli anti-aircraft forces. Mil. Med. 170: 710-712.

Gamble, R.P., Stevens, A.B., McBrien, H., Black, A., Cran, G.W., and Boreham, C.A. 1991. Physical fitness and occupational demands of the Belfast ambulance service. Br. J. Ind. Med. 48: 592-6. 
Gaskill, S.E., Ruby, B.C., Walker, A.J., Sanchez, O.A., Serfass, R.C., and Leon, A.S. 2001. Validity and reliability of combining three methods to determine ventilatory threshold. Med. Sci. Sports. Exerc. 33: 1841-1848.

Gaskill, S.E., Walker, A.J., Serfass, R.A., Bouchard, C., Gagnon, J., Rao, D.C., Skinner, J.S., Wilmore, J.H., and Leon, A.S. 2001b. Changes in ventilatory threshold with exercise training in a sedentary population: the HERITAGE Family Study. Int. J. Sports. Med. 22: 586-592.

Gaskill, S.E., Domitrovich, J. and Ruby, B. 2009. Summary of 3 years of multiple studies with wildland firefighters. United States Forest Service Technical Reports, Missoula Technology and Development Center.

Gebhardt, D.L., Baker, T.A., and Sheppard, V.A. 1998. Development and validation of physical performance tests for physically demanding telecommunication jobs. Human Performance Systems, Inc., Hyattsville, MD.

Gebhardt, D.L., Baker, T.A., Volpe, E.K., and Billerbeck, K.T. 2009. Development and validation of physical performance tests for selection of orderfillers. Human Performance Systems, Inc., Beltsville, MD.

Gebhardt, D.L., Baker, T.A., and Polaki, J. 2011. Development and validation of physical performance tests for arson field investigator. Human Performance Systems, Inc., Beltsville, MD. 
Gebhardt, D.L., Baker, T.A., and Volpe, E.K. 2012. Development and validation of physical performance tests for Special Agents. Human Performance Systems, Inc., Beltsville, MD.

George, S.Z., Childs, J.D., Teyhen, D.S., Wu, S.S., Wright, A.C., Dugan, J.L., and Robinson, M.E. 2012. Predictors of occurrence and severity of first time low back pain episodes: findings from a military inception cohort. PLoS One, 7: e30597.

Gordon, C., Churchill, T., Clauser, C., Bradtmiller, B., McConville, J., Tebbetts, I., and Walker, R. 1988. 1988 Anthropometric survey of U.S. Army personnel: methods and summary statistics. Army Natick Research, Development and Engineering Center, Natick, MA.

Gwinn, D.E., Wilckens, J.H., McDevitt, E.R., Ross, G., and Kao, T.C. 2000. The relative incidence of anterior cruciate ligament injury in men and women at the United States Naval Academy. Am. J. Sports Med. 28: 98-102.

Hardy v. Stumpf. 1978. 7 Fair Empl. Prac. Cas. (BNA) 468 (Supp. Ct. Cal.).

Harman, E., Frykman, P., Palmer, C., Lammi, E., and Reynolds, K. 1997. Effects of a specifically designed physical conditioning program on the load carriage and lifting performance of female soldiers. Army Research Institute of Environmental Medicine, Natick, MA.

Harman, E.A., Gutekunst, D.J., Frykman, P.N., Nindl, B.C., Alemany, J.A., Mello, R.P., and Sharp, M.A. 2008. Effects of two different eight-week training programs on military physical performance. J.Strength Cond. Res. 22: 524-534. 
Harvey, Sheridan. Rosie the riveter: real women workers in World War II. U.S. Library of Congress video, 14:19. 2005. http://www.loc.gov/rr/program/journey/rosie.html.

Hewett, T.E., Ford, K.R., Hoogenboom, B.J., and Myer, G.D. 2010. Understanding and preventing acl injuries: current biomechanical and epidemiologic considerations - update 2010. N. Am. J. Sports Phys. Ther. 5: 234-251.

Hewett, T. E., Myer, G. D., and Ford, K. R. 2006. Anterior cruciate ligament injuries in female athletes: Part 1, mechanisms and risk factors. Am. J. Sports. Med. 34: 299-311.

Hicks, A.L., Kent-Braun, J., and Ditor, D.S. 2001. Sex differences in human skeletal muscle fatigue. Exerc. Sport Sci. Rev. 29: 109-112.

Hinkle, D.E., Wiersma, W., and Jurs, S.G. 1994. Applied statistics for the behavioral sciences. Houghton Mifflin Harcourt, Boston, MA.

Hogan, J., Arneson, S., and Petersons, A.V. 1992. Validation of physical ability tests for high pressure cleaning occupations. J. Bus. Psychol. 7: 119-135.

Hulett, D.M., Bendick, M.J., Thomas, S.Y., and Moccio, F. 2008. Enhancing women's inclusion in firefighting in the USA. Int. J. Divers. Organ. Communities. Nations. 8: 189207.

Inoue, Y., Tanaka, Y., Omori, K., Kuwahara, T., Ogura, Y., and Ueda, H. 2005. Sex and menstrual cycle-related differences in sweating and cutaneous blood flow in response to passive heat exposure. Eur. J. Appl. Psychol. 94: 323-332. 
Jackson, A.S. 1994. Pre-employment physical evaluation. Exerc. Sport Sci. Rev. 22: 5390.

Jamnik, V.K., Thomas, S.G., Burr, J.F., and Gledhill, N. 2010a. Construction, validation, and derivation of performance standards for a fitness test for correctional officer applicants. Appl. Physiol. Nutr. Metab. 35: 59-70.

Jamnik, V.K., Thomas, S.G., and Gledhill, N. 2010b. Applying the meiorin decision requirements to the fitness test for correctional officer applicants: examining adverse impact and accommodation. Appl. Physiol. Nutr. Metab. 35: 71-81.

Jamnik,V.K., Thomas,S.G., Shaw, J.A. and Gledhil,N. 2010c. Identification and characterization of the critical physically demanding tasks encountered by correctional officers. Appl Physiol. Nutr. Metab. 35: 45-58.

Jones, B. H., Bovee, M. W., Harris, J. M., 3rd, and Cowan, D. N. 1993. Intrinsic risk factors for exercise-related injuries among male and female army trainees. Am. J. Sports Med. 21: 705-710.

Kalkowski, K.L. and Fritz, S. 2004. A survey of gender-related motivation studies: subordinate status, roles, and stereotyping. The Journal of Leadership Education. 3: 1934.

Knapik, J.J., Wright, J.E., Kowal, D.M., and Vogel, J.A. 1980. The influence of U.S. Army basic initial entry training on the muscular strength of men and women. Aviat. Space. Environ. Med. 51: 1086-1090. 
Knapik, J., Banderet, L., Bahrke, M., O'Connor, J., Jones, B., Vogel,J. 1994. Army Phsycial Fitness test (APFT) normative data on 6022 Soldiers. USARIEM Technical Report T94-7.

Knapik, J.J. and Gerber, J. 1996. The influence of physical fitness training on the manual material-handling capability and road-marching performance of female soldiers.U.S. Army Research Laboratory, Aberdeen Proving Ground, MD.

Knapik, J.J. and Sharp, M.A. 1998. Task-specific and generalized physical training for improving manual-material handling capability. Int. J. Ind. Ergon. 22: 149-160.

Knapik, J.J., Reynolds, K.L., and Harman, E. 2004. Soldier load carriage: historical, physiological, biomechanical, and medical aspects. Mil. Med. 169: 45-56.

Knapik, J., Darakjy, S., Scott, S. J., Hauret, K. G., Canada, S., Marin, R., Rieger, W., and Jones, B. H. 2005. Evaluation of a standardized physical training program for basic combat training. J. Strength Cond. Res. 19: 246-253.

Knapik, J.J., Jones, S.B., Darakjy, S., Hauret, K.G., Bullock, S.H., Sharp, M.A., and Jones, B.H. 2007. Injury rates and injury risk factors among U.S. Army wheel vehicle mechanics. Mil. Med. 172: 988-996.

Knapik, J.J., Grier, T., Spiess, A., Swedler, D.I., Hauret, K.G., Graham, B., Yoder, J., and Jones, B.H. 2011a. Injury rates and injury risk factors among Federal Bureau of Investigation new agent trainees. BMC Public Health. 11: 920. 
Knapik, J.J., Spiess, A., Swedler, D., Grier, T., Hauret, K., Yoder, J., and Jones, B.H. 2011b. Retrospective examination of injuries and physical fitness during Federal Bureau of Investigation new agent training. J. Occup. Med. Toxicol. 6: 26.

Kraemer, W.J. 2004. Effects of concurrent resistance and aerobic training on loadbearing performance and the Army Physical Fitness Test. Mil. Med. 169: 994-999.

Lanning v. Southeastern Pennsylvania Transportation Authority (SEPTA). 1999. 181 F.3d 478, 482-484 (3rd Cir.).

Lanning v. Southeastern Pennsylvania Transportation Authority (SEPTA). 2002. 308 F.3d 286 (3rd Cir.).

Lappe, J., Cullen, D., Haynatzki, G., Recker, R., Ahlf, R., and Thompson, K. 2008.

Calcium and vitamin D supplementation decreases incidence of stress fractures in female navy recruits. J. Bone Miner. Res. 23: 741-749.

Laubach, L. 1976. Comparative muscular strength of men and women: a review of the literature. Aviat. Space. Environ. Med. 47: 534-542.

Leenders, M., Verdijk, L.B., van der Hoeven, L., van Kranenburg, J., Nilwik, R., and van Loon, L.J.C. 2013. Elderly men and women benefit equally from prolonged resistancetype exercise training. Gerontol. A. Biol. Sci. Med. Sci. 68: 769-779.

Leipold, J.D. 2012. "The Official Homepage of the US Army: Women soldiers to test female-specific body armor." Army.mil.

http://www.army.mil/article/83986/Women Soldiers to test female specific body armor I [accessed October 1, 2015]. 
Lindle, R.S., Metter, E.J., Lynch, N.A., Fleg, J.L., Fozard, J.L., Tobin, J., Roy, T.A., and Hurley, B.F. 1997. Age and gender comparisons of muscle strength in 654 women and men aged 20-93 yr. J. Appl. Physiol. 83: 1581-7.

Malina, R.M. and Bouchard, C. 1991. Growth, maturation and physical activity. Human Kinetics Academics, Champaign, IL.

McLellan, T.M. 1998. Sex-related differences in thermoregulatory responses while wearing protective clothing. Eur. J. Appl. Psychol. Occup. Physiol. 78: 28-37.

Miller, A.E.J., MacDougall, J.D., Tarnopolsky, M.A., and Sale, D.G. 1993. Gender differences in strength and muscle fiber characteristics. Eur. J. Appl. Psychol. 66: 254262.

Murphy, M.M., Patton, J., Mello, R., Bidwell, T., and Harp, M. 2001. Energy cost of physical task performance in men and women wearing chemical protective clothing. Aviat. Space. Environ. Med. 72: 25-31.

Myer, G.D., Ford, K.R., Foss, K.D.B., Rauh, M.J., Paterno, M.V., and Hewett, T.E. 2014. A predictive model to estimate knee-abduction moment: Implications for development of a clinically applicable patellofemoral pain screening tool in female athletes. J. Athl. Train.

49: 389-398.

Nindl, B.C., 2015. Physical training strategies for military women's performance optimization in combat-centric occupations. J. Strength Cond. Res. 29: S101-S106. 
Nindl, B.C., Mahar, M.T., Harman, E.A., and Patton, J.F. 1995. Lower and upper body anaerobic performance in male and female adolescent athletes. Med. Sci. Sports. Exerc. 27: 235-241.

Nordander, C., Ohlsson, K., Balogh, I., Hansson, G.A., Axmon, A., Persson, R., and Skerfving, S. 2008. Gender differences in workers with identical repetitve industrial tasks: exposure and musculoskeletal disorders. Int. Arch. Occup. Environ. Health. 81: 939-947.

Ogawa, T., Spina, R.J., Martin, W.H., 3rd, Kohrt, W.M., Schechtman, K.B., Holloszy, J.O., and Ehsani, A.A. 1992. Effects of aging, sex, and physical training on cardiovascular responses to exercise. Circulation. 86: 494-503.

O'Leary, R. S., Gebhardt, D.L., Baker, T.A., Billerbeck, K.T., Volpe, E.K., \& Hansen, A.M. (2009). U.S. Customs and Border Protection: Development and validation of a physical fitness test for the Customs and Border Patrol officer position. Arlington, VA: PDRI: A PreVisor Company.

Pimentel, A.E., Gentile, C.L., Tanaka, H., Seals, D.R., and Gates, P.E. 2003. Greater rate of decline in maximal aerobic capacity with age in endurance-trained than in sedentary men. J. Appl. Physiol. 94: 2406-2413.

Reilly, R.R., Zedeck, S., and Tenopyr, M.L. 1979. Validity and fairness of physical ability tests for predicting performance in craft jobs. J. Appl. Psychol. 64: 262.

Renee Barlow, K., Henriksen, P.R., and Metcalfe, D. 1993. Estimating load size in the Great Basin: data from conical burden baskets. Utah Archeology. 6: 27-37. 
Roberts, D. 2004. Exceptionally high plasma cortisols and IL-6 levels in reforestation workers. Med. Sci. Sports. Exerc. 36: S220.

Roberts, D. 2006. Changes in blood pressure with 3-weeks of electrolyte-carbohydrate beverage consumption. J. Occup. Environ. Hyg. 3: 131-136.

Roberts, D. 2009. The occupational athlete: injury reduction and productivity enhancement in reforestation workers. In ACSM's Worksite Health Handbook: A Guide to Building Healthy Companies. Edited by N.P. Pronk. Human Kinetics, Champaign, IL. pp. 309-316.

Roberts, D. 2013. Injury prevention for ski-area employees: a physiological assessment of lift operators, instructors, and patrollers. BioMed. Res. Int. www.hindawi.com/journals/bmri/2013/121832/

Rohde,U., Sievert,A. Rüther,T., Witzki, A. Leyk,D. 2015. Concept for a -ness in the German armed forces. J Strength Cond Res, 29: S211-215.

Roy, T.C., Piva, S.R., Christiansen, B.C., Lesher, J.D., Doyle, P.M., Waring, R.M., Irrgang, J.J., Moore, C.G., Brininger, T.L., and Sharp, M.A. 2015a. Description of musculoskeletal injuries occurring in female soldiers deployed to Afghanistan. Mil. Med. 180: $269-275$.

Roy, T.C., Ritland, B.M., and Sharp, M.A. 2015b. A description of injuries in men and women while serving in Afghanistan. Mil. Med. 180: 126-131. 
Savage, R.J., Best, S.A., Carstairs, G.L., Ham, D.J., and Doyle, T.L.A. 2014. On the relationship between discrete and repetitive lifting performance in military tasks. J. Strength. Cond. Res. 28: 767-773.

Sex Discrimination Act 1984 (Act No.4, 1984). [Australia]

Sharkey, B.J. 2008. Wildland firefighter health and safety report: No. 12. USDA Forest Service Missoula Development and Technology Center, Missoula, MT

Sharkey, B.J. and Gaskill, S.E. 2009. Fitness and work capacity. In National Wildfire Coordinating Group, Safety and Health Working Team. National Interagency Fire Center, Boise, ID.

Sharp, M.A. 1994. Physical fitness and occupational performance of women in the U.S. Army Work. 4: 80-92.

Sharp, M.A., Knapik, J.J., and Schoppert, A.W. 1994. Energy cost and efficiency of a demanding combined manual materials-handling task. Work. 4: 162-170.

Sharp, M.A., Knapik, J.J., Patton, J.F., Hauret, K., Mello, R.P., Ito, M.A., and Frykman, P.N. 2002. Comparison of the physical fitness of men and women entering the U.S. Army: 1978-1998. Med. Sci. Sports and Exerc., 34: 356-363.

Smith v. Des Moines. 1996. \#95-3802, 99 F.3d 1466, 1996 U.S. App. Lexis 29340, 72 FEP Cases (BNA) 628, 6 AD Cases (BNA) 14 (8th Cir.).

Society for Industrial and Organizational Psychology. 2003. Principles for the validation and use of personnel selection procedures. Bowling Green, $\mathrm{OH}$. 
Solianik, R., Skurvydas, A., Mickevičienè, D., and Brazaitis, M. 2014. Intermittent wholebody cold immersion induces similar thermal stress but different motor and cognitive responses between males and females. Cryobiology. 69: 323-332.

Sothmann, M.S., Gebhardt,D.L., Baker,T.A., Kastello,G.M.m Sheppard,V.A. 2004. Perfromance requirements of physically strenguous occupations: validating minimum standards for muscular strength and endurance. Ergonom, 47: 864-875,

Stacy Ernst et al. v. City of Chicago. 2015. Illinois Northern District Court [No. 8-CV4370].

Strowbridge, N. F. 2005. Gender differences in the cause of low back pain in British soldiers. J. R. Army Med. Corps. 151: 69-72.

Taylor, N.A. 2014. Human heat adaptation. Compr. Physiol. 4: 325-365.

Teyhen, D., Bergeron, M.F., Deuster. P., Baumgartner, N., Beutler. A.I., de la Motte, S.J., Jones, B.H., Lisman, P., Padua, D.A., Pendergrass, T.L., Pyne, S.W., Schoomaker, E., Sell, T.C., and O'Connor, F. 2014. Consortium for health and military performance and American College of Sports Medicine Summit: utility of functional movement assessment in identifying musculoskeletal injury risk. Curr. Sports. Med. Rep. 13: 52-63.

The Equality Act 2010. The National Archieves. Retrieved March 2013. (United States).

Tikuisis, P., Jacobs, I., Moroz, D., Vallerand, A., and Martineau, L. 2000. Comparison of thermoregulatory responses between men and women immersed in cold water. J. Appl. Physiol. 89: 1403-1411. 
U.S. Library of Congress 2005. Rosie the Riveter: Real Women Workers in World War II.

United States v. City of Erie, P. 2005. \#04-4, 352 F. Supp. 2d 1105 (W.D. Pa.).

Wilmore, J.H., Costill,D.L. and Kenney, W.L. 2008. Physiology of Sport and Exercise, Human Kinetics, $4^{\text {th }}$ Edition, Champaign, IL, pp425.

Vogel, J.A., Patton, J.F., Mello, R.P., and Daniels, W.L. 1986. An analysis of aerobic capacity in a large United States population. J. Appl. Physiol. 60: 494-500.

Yanovich, R., Evans, R., Israeli, E., Constantini, N., Sharvit, N., Merkel, D., Epstein, Y., and Moran, D.S. 2008. Differences in physical fitness of male and female recruits in gender-integrated army basic training. Med. Sci. Sports. Exerc.. 40: S654-S659. 
Table 1. Sex Differences in Upper Body Strength and Endurance Basic Abilities Tests and Job Task Simulations. The W/M score is the percentage of the men's score that women achieved. Where a lower score represents a better physical performance, the inverse ratio is reported (M/W x 100).

\begin{tabular}{|c|c|c|c|c|c|c|}
\hline Task & Study Group & Men & Women & $\begin{array}{c}\text { W/M Score } \\
\text { Mean } \\
\text { (range) }\end{array}$ & Sample & Reference \\
\hline \multicolumn{7}{|c|}{ Upper Body Strength Basic Fitness Component Tests } \\
\hline Grip Strength (kg) & Police Officers & $62.9^{*}$ & 40.9 & $65 \%$ & $96 \mathrm{M}: 19 \mathrm{~W}$ & Arvey et al. 1992 \\
\hline Grip strength (kg) & $\begin{array}{l}\text { Emergency Medical } \\
\text { Technician }\end{array}$ & $48.0^{*}$ & 33.0 & $69 \%$ & $91 \mathrm{M}: 11 \mathrm{~W}$ & Gamble et al. 1991 \\
\hline Grip strength $(\mathrm{kg})$ & Outdoor telephone crafters & $60.3^{*}$ & 40.6 & $67 \%$ & $83 \mathrm{M}: 45 \mathrm{~W}$ & Reilly et al. 1979 \\
\hline Grip strength (kg) & $\begin{array}{l}\text { Carpenters, builders, } \\
\text { warehouse personnel }\end{array}$ & $53.3^{*}$ & 38.9 & $73 \%$ & 12,183M:194W & Blakley et al. 1994 \\
\hline Grip Strength (kg) & Grocery Order Fillers & $46.8^{*}$ & 31.7 & $68 \%$ & 113M:51W 31 & Gebhardt et al. 2009 \\
\hline Grip Strength (kg) & Special Agents & $50.8^{*}$ & 33.0 & $65 \%$ & 145M:46W 24 & Gebhardt et al. 2012 \\
\hline Grip Strength (kg) & Customs Officers & $46.5^{*}$ & 26.1 & $56 \%$ & 86M:47W 35 & O'Leary et al. 2009 \\
\hline Grip Strength (kg) & Correctional Officers & $57.7^{*}$ & 37.7 & $65 \%$ & 51M:36W & Jamnik et al. 2010 \\
\hline Grip Strength (kg) & Telecommunication Workers & $55.4^{*}$ & 34.7 & $63 \%$ & 191M:33W 15 & Gebhardt et al. 1998 \\
\hline Grip Strength (kg) & German Soldiers & $55.8^{*}$ & 35.1 & $63 \%$ & 104M:18W & Rohde et al. 2015 \\
\hline Grip Strength (kg) & American Soldiers & $46.4^{*}$ & 29.9 & $65 \%$ & $606 \mathrm{M}: 230 \mathrm{~W}$ & Foulis et al. 2015 \\
\hline $\begin{array}{l}\text { Grip Strength (kg) } \\
\text { Weighted Mean }\end{array}$ & $\begin{array}{l}\text { Law Enforcement, } \\
\text { Emergency Medical } \\
\text { Technicians, Outdoor } \\
\text { Telephone crafters, } \\
\text { Telecommunication } \\
\text { Workers, Soldiers, Grocery } \\
\text { Order Fillers }\end{array}$ & 53.0 & 34.1 & $64 \%,(56 \%-73 \%)$ & 13749M:730W & $\begin{array}{l}\text { Arvey et al. 1992; } \\
\text { Blakley et al. 1994; } \\
\text { Foulis et al. 2015; } \\
\text { Gamble et al. 1991; } \\
\text { Gebhardt et al. 1998; } \\
\text { Gebhardt et al. 2009; } \\
\text { Gebhardt et al. 2012; } \\
\text { Jamnik et al. 2010; } \\
\text { O'Leary et al. 2009; } \\
\text { Reilly et al. 1979; } \\
\text { Rohde et al. 2015 }\end{array}$ \\
\hline $\begin{array}{l}\text { Isometric arm curl } \\
\text { strength }(\mathrm{kg})\end{array}$ & $\begin{array}{l}\text { Carpenters, builders, } \\
\text { warehouse personnel }\end{array}$ & $41.9 *$ & 29.7 & $71 \%$ & 12,183M:194W & Blakley et al. 1994 \\
\hline $\begin{array}{l}\text { Isometric arm curl } \\
\text { strength }(\mathrm{kg})\end{array}$ & German Soldiers & $24.0^{*}$ & 12.1 & $50 \%$ & 104M:18W & Rohde et al. 2015 \\
\hline $\begin{array}{l}\text { Isometric arm curl } \\
\text { strength }(\mathrm{kg})\end{array}$ & American Soldiers & $46.3^{*}$ & 27.1 & $59 \%$ & $608 \mathrm{M}: 230 \mathrm{~W}$ & Foulis et al. 2015 \\
\hline $\begin{array}{l}\text { Isometric arm curl } \\
\text { strength (kg) } \\
\text { Weighted Mean }\end{array}$ & $\begin{array}{l}\text { Law Enforcement, Soldiers, } \\
22 \text { industrial jobs to include } \\
\text { carpenters, builders, } \\
\text { warehouse personnel }\end{array}$ & 46.3 & 27.1 & $\begin{array}{c}59 \% \\
(50 \%-71 \%)\end{array}$ & 12910M:442W & $\begin{array}{l}\text { Blakley et al. 1994; } \\
\text { Foulis et al. 2015; } \\
\text { Rohde et al. } 2015\end{array}$ \\
\hline Bench Press (kg) & Wildland Firefighters & $126.0^{*}$ & 90.8 & $72 \%$ & 97M:16W & Gaskill et al. 2009 \\
\hline Bench Press (kg) & Firefighters & $93.4^{*}$ & 52.3 & $56 \%$ & $818 \mathrm{M}: 36 \mathrm{~W}$ & Boyce et al. 2008 \\
\hline Bench Press (kg) & Police & $96.3^{*}$ & 43.9 & $46 \%$ & 1181M:195W & Boyce et al. 2008 \\
\hline $\begin{array}{l}\text { Bench Press (kg) } \\
\text { Weighted Mean }\end{array}$ & Firefighters, Police & 96.5 & 48.0 & $\begin{array}{c}50 \% \\
(46 \%-72 \%)\end{array}$ & 2096M:237W & $\begin{array}{l}\text { Boyce et al. 2008; } \\
\text { Gaskill et al. } 2009\end{array}$ \\
\hline Arm Lift (kg) & Grocery Order Fillers & $49.0^{*}$ & 28.9 & $59 \%$ & $113 \mathrm{M}: 51 \mathrm{~W}$ & Gebhardt et al. 2009 \\
\hline Arm Lift (kg) & Special Agents & $45.4^{*}$ & 26.3 & $58 \%$ & 145M:46W & Gebhardt et al. 2012 \\
\hline Arm Lift (kg) & Telecommunication Workers & $42.8^{*}$ & 25.4 & $59 \%$ & 191M:33W & Gebhardt et al. 1998 \\
\hline Arm Lift (kg) & Customs Officers & $42.0^{*}$ & 22.3 & $53 \%$ & $86 \mathrm{M}: 47 \mathrm{~W}$ & O'Leary et al. 2009 \\
\hline $\begin{array}{l}\text { Straight Arm Lift } \\
\text { (kg) Weighted } \\
\text { Mean }\end{array}$ & $\begin{array}{l}\text { Grocery Order Fillers, } \\
\text { Telecom Workers, Special } \\
\text { Agents, Customs Officers }\end{array}$ & 44.7 & 25.8 & $58 \%$ & 535M:177W & $\begin{array}{c}\text { Gebhardt et al. 1998; } \\
\text { Gebhardt et al. 2009; } \\
\text { Gebhardt et al. 2012; } \\
\text { O'Leary et al. 2009 }\end{array}$ \\
\hline
\end{tabular}




\begin{tabular}{|c|c|c|c|c|c|c|}
\hline \multicolumn{7}{|c|}{ Upper Body Strength Job Task Simulations } \\
\hline $\begin{array}{l}\text { Inmate wrist hold } \\
\text { force }(\mathrm{kg})\end{array}$ & Correctional Officers & $49.1^{*}$ & 32.3 & $66 \%$ & $51 \mathrm{M}: 36 \mathrm{~W}$ & Jamnik et al. 2010c \\
\hline $\begin{array}{l}\text { Inmate arm } \\
\text { retraction force }(\mathrm{kg})\end{array}$ & Correctional Officers & $46.8^{*}$ & 37.3 & $80 \%$ & $51 \mathrm{M}: 36 \mathrm{~W}$ & Jamnik et al. 2010c \\
\hline $\begin{array}{l}\text { Control inmate: push } \\
\text { force }(\mathrm{kg})\end{array}$ & Correctional Officers & $60.0^{*}$ & 45.9 & $77 \%$ & $51 \mathrm{M}: 36 \mathrm{~W}$ & Jamnik et al. 2010c \\
\hline $\begin{array}{l}\text { Control inmate: pull } \\
\text { force }(\mathrm{kg})\end{array}$ & Correctional Officers & $64.1 *$ & 47.7 & $74 \%$ & $51 \mathrm{M}: 36 \mathrm{~W}$ & Jamnik et al. 2010c \\
\hline Hang an autopour ${ }^{\wedge}$ & Steelworkers & $5.8^{*}$ & 2.0 & $34 \%$ & 57M:21W & Arnold et al. 1982 \\
\hline Hook a chain ${ }^{\wedge}$ & Steelworkers & $6.8^{*}$ & 5.1 & $75 \%$ & 104M:48W & Arnold et al. 1982 \\
\hline \multicolumn{7}{|c|}{ Upper Body Muscular Endurance Basic Fitness Component Tests } \\
\hline Push-ups to failure & FBI Agents & $40.6^{*}$ & 23.6 & $58 \%$ & 2576M:655W & Knapik et al. 2011b \\
\hline Push-ups to failure & Wildland Firefighters & $62.5^{*}$ & 41.3 & $61 \%$ & 97M:16W & Gaskill et al. 2009 \\
\hline $\begin{array}{l}\text { Push-ups (number in } 1 \\
\text { min) }\end{array}$ & Special Agents & $48.8^{*}$ & 30.9 & $63 \%$ & 145M:46W & Gebhardt et al. 2012 \\
\hline $\begin{array}{l}\text { Push-ups (number in } 1 \\
\text { min) }\end{array}$ & Customs Officers & $45.2^{*}$ & 16.8 & $37 \%$ & $86 \mathrm{M}: 47 \mathrm{~W}$ & O'Leary et al. 2009 \\
\hline $\begin{array}{l}\text { Push-ups (number in } 1 \\
\text { min) }\end{array}$ & US Soldiers & $50.0^{*}$ & 31.0 & $62 \%$ & 608M:230W & Foulis et al. 2015 \\
\hline Push-ups & $\begin{array}{l}\text { Law Enforcement, Wildland } \\
\text { Firefighters, Soldiers }\end{array}$ & $43.3^{*}$ & 25.6 & $\begin{array}{c}59 \% \\
(37 \%-63 \%)\end{array}$ & 3482M:980W & $\begin{array}{c}\text { Foulis et al. 2015; } \\
\text { Gaskill et al. 2009; } \\
\text { Gebhardt et al. 2012; } \\
\text { Knapik et al. 2011b; } \\
\text { O'Leary et al. } 2009\end{array}$ \\
\hline Pull-ups to failure & FBI Agents & $8.4^{*}$ & 1.1 & $13 \%$ & 2546M:641W & Knapik et al. 2011b \\
\hline Pull-ups to failure & Wildland Firefighters & $12.4^{*}$ & 5.6 & $45 \%$ & $97 \mathrm{M}: 16 \mathrm{~W}$ & Gaskill et al. 2009 \\
\hline Pull-ups to failure & $\begin{array}{l}\text { FBI Agents, Wildland } \\
\text { Firefighters }\end{array}$ & 8.5 & 1.2 & $\begin{array}{c}14 \% \\
(13 \%-45 \%)\end{array}$ & 2643M:657W & $\begin{array}{l}\text { Gaskill et al. 2009; } \\
\text { Knapik et al. 2011b }\end{array}$ \\
\hline Bench dips in $1 \mathrm{~min}$ & Police Officers & 31.6 & 27.1 & $86 \%$ & 96M:19W & Arvey et al. 1992 \\
\hline $\begin{array}{l}\text { Arm Endurance } \\
\text { (rev/min) }\end{array}$ & Grocery Order Fillers & $116.8^{*}$ & 82.1 & $70 \%$ & $113 \mathrm{M}: 51 \mathrm{~W}$ & Gebhardt et al. 2009 \\
\hline $\begin{array}{l}\text { Arm Endurance } \\
\text { (revs/min) }\end{array}$ & Special Agents & $137^{*}$ & 108.8 & $79 \%$ & 145M:46W & Gebhardt et al. 2012 \\
\hline $\begin{array}{l}\text { Arm Endurance } \\
\text { (rev/ } \mathrm{min} \text { ) }\end{array}$ & Customs Officers & $119.6^{*}$ & 92.4 & $77 \%$ & $86 \mathrm{M}: 47 \mathrm{~W}$ & O'Leary et al. 2009 \\
\hline $\begin{array}{l}\text { Arm Endurance } \\
\text { (rev/ min) }\end{array}$ & $\begin{array}{l}\text { Telecommunication } \\
\text { Workers }\end{array}$ & $93.0 *$ & 68.0 & $73 \%$ & 191M:33W & Gebhardt et al. 1998 \\
\hline $\begin{array}{l}\text { Arm Endurance } \\
\text { (rev/min) }\end{array}$ & American Soldiers & $130.5^{*}$ & 97.5 & $75 \%$ & 608M:230W & Foulis et al. 2015 \\
\hline $\begin{array}{l}\text { Arm Endurance } \\
\text { (rev/min) } \\
\text { Weighted Mean }\end{array}$ & $\begin{array}{l}\text { Law Enforcement, Grocery } \\
\text { Order Fillers, Telecom } \\
\text { Workers, American Soldiers }\end{array}$ & 122.9 & 93.9 & $\begin{array}{c}76 \% \\
(70 \%-79 \%)\end{array}$ & 1143M:407W & $\begin{array}{c}\text { Foulis et al. 2015; } \\
\text { Gebhardt et al. 1998; } \\
\text { Gebhardt et al. 2009; } \\
\text { Gebhardt et al. 2012; } \\
\text { O'Leary et al. } 2009\end{array}$ \\
\hline \multicolumn{7}{|c|}{ Upper Body Endurance Job Task Simulations } \\
\hline $\begin{array}{l}\text { Use } 3 \mathrm{~m} \text { pole to set } \\
12-9 \mathrm{lb} \text { bags up to } 4 \mathrm{~m}^{\wedge}\end{array}$ & Steelworkers & $6.3^{*}$ & 3.2 & $51 \%$ & $57 \mathrm{M}: 21 \mathrm{~W}$ & Arnold et al. 1982 \\
\hline $\begin{array}{l}\text { Pulaski Treadmill } \\
\text { revs } / \mathrm{min} 5 \mathrm{~min}\end{array}$ & Wildland Firefighters & $22.6^{*}$ & 16.8 & $74 \%$ & 97M:16W & Gaskill et al. 2009 \\
\hline $\begin{array}{l}\text { Shovel slag (inch/15 } \\
\text { min) }\end{array}$ & Steelworkers & $63.2^{*}$ & 33.9 & $54 \%$ & 167M:76W & Arnold et al. 1982 \\
\hline $\begin{array}{l}\text { Cut tie wire for } 3 \\
\text { minutes (number cut) }\end{array}$ & Steelworkers & $66.3^{*}$ & 23.6 & $36 \%$ & $57 \mathrm{M}: 21 \mathrm{~W}$ & Arnold et al. 1982 \\
\hline
\end{tabular}

$\mathrm{M}=$ male, $\mathrm{W}=$ female, $\mathrm{FBI}=$ Federal Bureau of Investigation, $\mathrm{US}=$ United States, $\mathrm{min}=$ minutes, revs $/ \mathrm{min}$

$=$ revolutions $/$ minute, $\mathrm{kg}=$ kilograms, $\mathrm{lb}=$ pounds, $\mathrm{m}=$ meters .

*Significantly better performance when reported.

^Rating Scale: 1 (low) to 7 (high). 
Table 2. Sex Differences in Lower Body Strength, Endurance and Flexibility Basic Abilities Tests. The W/M score is the percentage of the men's score that women achieved. Where a lower score represents a better physical performance, the inverse ratio is reported (M/W x 100).

\begin{tabular}{|c|c|c|c|c|c|c|}
\hline \multicolumn{7}{|c|}{ Lower Body Strength Basic Fitness Component Tests } \\
\hline $\begin{array}{l}\text { Leg dynamometer } \\
(\mathrm{kg})\end{array}$ & Steelworkers & $132.3^{*}$ & 76.9 & $58 \%$ & 167M:76W & Arnold et al. 1982 \\
\hline Isometric Leg Lift (kg) & Telecommunication Workers & $113.5^{*}$ & 76.5 & $67 \%$ & 191M:33W & Gebhardt et al. 1998 \\
\hline Leg Lift (kg) & US soldiers & $147.1^{*}$ & 88.9 & $60 \%$ & $608 \mathrm{M}: 230 \mathrm{~W}$ & Foulis et al. 2015 \\
\hline $\begin{array}{l}\text { Isometric Leg Lift (kg) } \\
\text { Weighted Mean }\end{array}$ & $\begin{array}{l}\text { Telecommunication Workers, } \\
\text { American Soldiers }\end{array}$ & 139.1 & 87.3 & $\begin{array}{c}62 \% \\
(58 \%-67 \%)\end{array}$ & $896 \mathrm{M}: 279 \mathrm{~W}$ & $\begin{array}{c}\text { Arnold et al. 1982; } \\
\text { Foulis et al. 2015; } \\
\text { Gebhardt et al. 1998 }\end{array}$ \\
\hline Squat max (kg) & Wildland Firefighters & 147.7 & 112.8 & $76 \%$ & 97M:16W & Gaskill et al. 2009 \\
\hline Knee extension (kg) & German Soldiers & $64.4^{*}$ & 44.2 & $69 \%$ & 104M:18W & Rohde et al., 2015 \\
\hline \multicolumn{7}{|c|}{ Leg Endurance Basic Fitness Component Tests } \\
\hline $\begin{array}{l}\text { Leg Endurance } \\
\text { (rev/2 } \mathrm{min})\end{array}$ & Telecommunication Workers & $182.8^{*}$ & 138.0 & $75 \%$ & 191M:33W & Gebhardt et al. 1998 \\
\hline \multicolumn{7}{|c|}{ Flexibility Basic Fitness Component Tests } \\
\hline Trunk flexibility $(\mathrm{cm})$ & $\begin{array}{l}\text { Emergency Medical } \\
\text { Technician }\end{array}$ & 17.4 & $20.7^{*}$ & $119 \%$ & $91 \mathrm{M}: 11 \mathrm{~W}$ & Gamble et al. 1991 \\
\hline Sit and Reach $(\mathrm{cm})$ & Telecommunication Workers & 24.7 & $29.7^{*}$ & $120 \%$ & 191M:33W & Gebhardt et al. 1998 \\
\hline Sit \& Reach $(\mathrm{cm})$ & Customs Officers & 27.9 & $31.5^{*}$ & $113 \%$ & $86 \mathrm{M}: 47 \mathrm{~W}$ & O'Leary et al. 2009 \\
\hline $\begin{array}{l}\text { Sit \& Reach }(\mathrm{cm}) \\
\text { Weighted Mean }\end{array}$ & $\begin{array}{l}\text { Telecommunications } \\
\text { workers, Customs officers }\end{array}$ & 25.7 & 30.8 & $120 \%$ & 277M:80W & $\begin{array}{l}\text { Gebhardt et al. 1998; } \\
\text { O'Leary et al. } 2009\end{array}$ \\
\hline
\end{tabular}

$\mathrm{M}=$ male, $\mathrm{W}=$ female, $\mathrm{US}=$ United States, $\mathrm{kg}=$ kilograms, $\mathrm{rev} / 2 \mathrm{~min}=$ revolutions in 2 minutes, $\mathrm{cm}=$

centimeters

*Significantly better performance when reported. 
Table 3. Sex Differences in Core and Full Body Strength/Power and Endurance Basic Abilities Tests and Job Task Simulations. The W/M score is the percentage of the men's score that women achieved. Where a lower score represents a better physical performance, the inverse ratio is reported $(M / W \times 100)$.

\begin{tabular}{|c|c|c|c|c|c|c|}
\hline \multicolumn{7}{|c|}{ Core Strength Basic Fitness Component Tests } \\
\hline Seated Trunk Pull (kg) & Grocery Order Fillers & $130.9^{*}$ & 85.8 & $66 \%$ & 113M:51W & Gebhardt et al. 2009 \\
\hline Seated Trunk Pull (kg) & Telecommunication Workers & $128.5^{*}$ & 83.4 & $65 \%$ & 191M:33W & Gebhardt et al. 1998 \\
\hline Seated Trunk Pull (kg) & Customs Officers & $117.5^{*}$ & 74.9 & $64 \%$ & $86 \mathrm{M}: 47 \mathrm{~W}$ & O'Leary et al. 2009 \\
\hline $\begin{array}{l}\text { Seated Trunk Pull (kg) } \\
\text { Weighted Mean }\end{array}$ & $\begin{array}{l}\text { Grocery Order Fillers, } \\
\text { Telecommunication Workers, } \\
\text { Customs Officers }\end{array}$ & 126.8 & 81.3 & $\begin{array}{c}64 \% \\
(64-66 \%)\end{array}$ & 390M:131W & $\begin{array}{c}\text { Gebhardt et al. 1998; } \\
\text { Gebhardt et al. 2009; } \\
\text { O'Leary et al. 2009 } \\
\end{array}$ \\
\hline \multicolumn{7}{|c|}{ Full Body Strength/Power Basic Fitness Component Tests } \\
\hline $\begin{array}{l}\text { Weight Stack Lift to } \\
152 \mathrm{~cm}\end{array}$ & US Soldiers & 76.8 & 40.0 & $52 \%$ & 182M:168W & Sharp et al. 2000 \\
\hline \multicolumn{7}{|c|}{ Full Body Strength/Power Job Task Simulations } \\
\hline $\begin{array}{l}123 \mathrm{~kg}, 15 \mathrm{~m} \text { Dummy } \\
\text { drag }(\mathrm{m} / \mathrm{sec})\end{array}$ & US Soldiers & $1.15^{*}$ & 0.42 & $37 \%$ & $608 \mathrm{M}: 230 \mathrm{~W}$ & Foulis et al. 2015 \\
\hline $\begin{array}{l}75 \mathrm{~kg}, 14.5 \mathrm{~m} \text { Dummy } \\
\mathrm{drag}(\mathrm{m} / \mathrm{sec})\end{array}$ & Firefighters & 0.26 & 0.22 & $86 \%$ & 138M:15W & Sothmann et al. 2004 \\
\hline $\begin{array}{l}\text { Dummy Drag }(\mathrm{m} / \mathrm{sec}) \\
\text { Weighted Mean }\end{array}$ & Soldiers, Firefighters & 0.99 & 0.41 & $\begin{array}{c}41 \% \\
(37 \%-86 \%) \\
\end{array}$ & $746 \mathrm{M}: 245 \mathrm{~W}$ & $\begin{array}{c}\text { Foulis et al. 2015; } \\
\text { Sothmann et al. } 2004\end{array}$ \\
\hline $\begin{array}{l}1.5 \mathrm{~m} \text { Box Lift and } \\
\text { Place (kg) }\end{array}$ & Australian Soldiers (trained) & $46.5^{*}$ & 24.9 & $54 \%$ & 154M:20W & Drain et al. 2015 \\
\hline \multicolumn{7}{|c|}{ Miscellaneous Job Task Simulations } \\
\hline \multicolumn{7}{|l|}{ Climbing } \\
\hline Agility Ladder (sec) & Special Agents & 70.9 & 72.7 & $96 \%$ & 145M:46W & Gebhardt et al. 2012 \\
\hline Ladder Climb (sec) & Telecommunication Workers & 189.6 & 204.4 & $93 \%$ & 191M:33W & Gebhardt et al. 1998 \\
\hline Pole Climb (sec) & Telecommunication Workers & 204.8 & 330.3 & $62 \%$ & 191M:33W & Gebhardt et al. 1998 \\
\hline Stabilometer (sec) & Telecommunication Workers & 10.5 & 11.7 & $111 \%$ & 191M:33W & Gebhardt et al. 1998 \\
\hline \multicolumn{7}{|c|}{ Core Muscular Endurance Basic Fitness Component Tests } \\
\hline Sit-ups in $1 \mathrm{~min}$ & Police Officers & 33.4 & 36.9 & $110 \%$ & $96 \mathrm{M}: 19 \mathrm{~W}$ & Arvey et al. 1992 \\
\hline Sit-ups in $1 \mathrm{~min}$ & FBI Agents & 50.2 & 49.8 & $99 \%$ & 2580M:655W & Knapik et al. $2011 b$ \\
\hline Sit-ups in $1 \mathrm{~min}$ & Grocery Order Fillers & $35.7^{*}$ & 23.0 & $64 \%$ & 113M:51W & Gebhardt et al. 2009 \\
\hline Sit-ups in $1 \mathrm{~min}$ & Special Agents & 49.5 & 50.0 & $101 \%$ & 145M:46W & Gebhardt et al. 2012 \\
\hline Sit-ups in $1 \mathrm{~min}$ & Telecommunication Workers & 33.2 & 30.0 & $90 \%$ & 191M:33W & Gebhardt et al. 1998 \\
\hline Sit-ups in $1 \mathrm{~min}$ & US. Army Soldiers & 46.0 & 45.0 & $100 \%$ & 607M:230W & Foulis et al. 2015 \\
\hline Sit-ups in 2 min & Wildland Firefighters & 87.1 & 94.0 & $108 \%$ & $97 \mathrm{M}: 16 \mathrm{~W}$ & Gaskill et al., 2009 \\
\hline $\begin{array}{l}\text { Sit-ups } \\
\text { Weighted Mean }\end{array}$ & $\begin{array}{l}\text { Law Enforcement, Grocery } \\
\text { Order Fillers, } \\
\text { Telecommunications } \\
\text { Workers, Firefighters, } \\
\text { Soldiers }\end{array}$ & 47.6 & 46.5 & $\begin{array}{c}98 \% \\
(64 \%- \\
110 \%)\end{array}$ & 3795M:1036W & $\begin{array}{l}\text { Arvey et al. 1992; } \\
\text { Foulis et al. 2015; } \\
\text { Gaskill et al., 2009; } \\
\text { Gebhardt et al. 1998; } \\
\text { Gebhardt et al. 2009; } \\
\text { Gebhardt et al. 2012; } \\
\text { Knapik et al. 2011b }\end{array}$ \\
\hline $\begin{array}{l}\text { Sit-ups (wearing } \\
\text { weight vest) in } 30 \mathrm{sec}\end{array}$ & Outdoor telephone crafters & $17.2^{*}$ & 12.2 & $71 \%$ & $83 \mathrm{M}: 45 \mathrm{~W}$ & Reilly et al. 1979 \\
\hline \multicolumn{7}{|c|}{ Whole Body Endurance Job Task Simulations } \\
\hline $\begin{array}{l}\text { number } 50 \mathrm{lb} \text { bags } \\
\text { moved in } 5 \mathrm{~min}\end{array}$ & Steelworkers & $38.1^{*}$ & 26.6 & $70 \%$ & 121M:150W & Arnold et al. 1982 \\
\hline $\begin{array}{l}\text { Wheelbarrowing } \\
\text { (rating 1-7) }\end{array}$ & Steelworkers & $6.7^{*}$ & 4.4 & $66 \%$ & 120M:48W & Arnold et al. 1982 \\
\hline $\begin{array}{l}\text { Transfer } 80 \mathrm{lb} \text { barbed } \\
\text { wire bales for } 5 \mathrm{~min} \\
\text { (number moved) }\end{array}$ & Steelworkers & $88.8^{*}$ & 42.3 & $48 \%$ & $57 \mathrm{M}: 21 \mathrm{~W}$ & Arnold et al. 1982 \\
\hline
\end{tabular}




\begin{tabular}{|l|l|c|c|c|c|c|}
$\begin{array}{l}\text { Lift \& lower } 75 \mathrm{lb} \\
\text { bags for } 5 \text { min (reps) }\end{array}$ & Steelworkers & $40.5^{*}$ & 12.3 & $30 \%$ & $104 \mathrm{M}: 48 \mathrm{~W}$ & Arnold et al. 1982 \\
\hline $\begin{array}{l}60 \text { \& } 90 \mathrm{lb} \\
\text { jackhammers carry }\end{array}$ & Steelworkers & $6.7^{*}$ & 5.9 & $88 \%$ & $104 \mathrm{M}: 48 \mathrm{~W}$ & Arnold et al. 1982 \\
\hline $\begin{array}{l}\text { Time to carry } 16 \\
\text { sandbags (sec) }\end{array}$ & US Soldiers & 130.2 & 177.0 & $74 \%$ & $437 \mathrm{M}: 187 \mathrm{~W}$ & Foulis et al. 2015 \\
\hline $\begin{array}{l}\text { Job task filling order } \\
\text { (sec) }\end{array}$ & Grocery Order Fillers & 583.6 & 704.3 & $83 \%$ & $113 \mathrm{M}: 51 \mathrm{~W}$ & Gebhardt et al. 2009 \\
\hline $\begin{array}{l}\text { Job productivity } \\
\text { measure }\end{array}$ & Grocery Order Fillers & 1.1 & 1.1 & $93 \%$ & $113 \mathrm{M}: 51 \mathrm{~W}$ & Gebhardt et al. 2009 \\
\hline $\begin{array}{l}\text { Lift and Carry } \\
\text { Equipment }\end{array}$ & Telecommunication Workers & $25.1^{*}$ & 21.0 & $83 \%$ & $191 \mathrm{M}: 33 \mathrm{~W}$ & Gebhardt et al. 1998 \\
\hline Hoist and Drag (sec) & Telecommunication Workers & $148.8^{*}$ & 176.4 & $84 \%$ & $191 \mathrm{M}: 33 \mathrm{~W}$ & Gebhardt et al. 1998 \\
\hline $\begin{array}{l}\text { Cargo Lift (number } \\
\text { moved in } 3 \text { min) }\end{array}$ & Customs Officers & $28.8^{*}$ & 24.2 & $84 \%$ & $86 \mathrm{M}: 47 \mathrm{~W}$ & O'Leary et al. 2009 \\
\hline
\end{tabular}

$\mathrm{M}=$ male, $\mathrm{W}=$ female, $\mathrm{FBI}=$ Federal Bureau of Investigation, $\mathrm{US}=$ United States, $\mathrm{kg}=$ kilograms, $\mathrm{lb}=$

pounds, $\mathrm{cm}=$ centimeters, $\mathrm{m}=$ meters, $\mathrm{sec}=$ seconds, $\min =$ minutes, reps $=$ repetitions .

*Significantly better performance when reported.

Rating Scale: 1 (low) to 7 (high).

${ }^{\#}$ Score is $\%$ of engineering Standard. Workers receive incentive pay for any productivity over $98 \%$ of the engineered standard for the distribution centers. 
Table 4. Sex Differences in Aerobic Power, Sprint and Agility Basic Abilities Tests and Job Task Simulations. The W/M score is the percentage of the men's score that women achieved. Where a lower score represents a better physical performance, the inverse ratio is reported (M/W x 100).

\begin{tabular}{|c|c|c|c|c|c|c|}
\hline \multicolumn{7}{|c|}{ Aerobic Power Basic Fitness Component Tests } \\
\hline $\mathrm{VO}_{2} \max (\mathrm{ml} / \mathrm{kg} / \mathrm{min})^{\wedge}$ & $\begin{array}{l}\text { Emergency Medical } \\
\text { Technician }\end{array}$ & $37.0^{*}$ & 32.0 & $86 \%$ & 91M:11W & Gamble et al. 1991 \\
\hline $\mathrm{VO}_{2} \max (\mathrm{ml} / \mathrm{kg} / \mathrm{min})$ & Wildland Firefighters & $56.2^{*}$ & 52.9 & $94 \%$ & 97M:16W & Gaskill et al. 2009 \\
\hline $\mathrm{VO}_{2} \max (\mathrm{ml} / \mathrm{kg} / \mathrm{min})$ & EMTs, Wildland Firefighters & 46.9 & 44.3 & $94 \%$ & $188 \mathrm{M}: 27 \mathrm{~W}$ & $\begin{array}{l}\text { Gamble et al. 1991; } \\
\text { Gaskill et al. 2009; }\end{array}$ \\
\hline $\begin{array}{l}\mathrm{VO}_{2} \text { submax VT } \\
(\mathrm{ml} / \mathrm{kg} / \mathrm{min})\end{array}$ & Wildland Firefighters & 35.2 & 34.3 & $97 \%$ & 97M:16W & Gaskill et al. 2009 \\
\hline $\begin{array}{l}\mathrm{VO}_{2} \text { submax } \\
(\mathrm{ml} / \mathrm{kg} / \mathrm{min}) \\
\end{array}$ & Grocery Order Fillers & 37.2 & 33.8 & $91 \%$ & $113 \mathrm{M}: 51 \mathrm{~W}$ & Gebhardt et al. 2009 \\
\hline $\begin{array}{l}\mathrm{VO}_{2} \text { submax } \\
(\mathrm{ml} / \mathrm{kg} / \mathrm{min})\end{array}$ & Special Agents & 35.1 & 33.6 & $96 \%$ & $145 \mathrm{M}: 46 \mathrm{~W}$ & Gebhardt et al. 2012 \\
\hline 1-mile run (Mi/min) & Outdoor telephone crafters & 145.8 & 144.5 & $99 \%$ & $96 \mathrm{M}: 19 \mathrm{~W}$ & Arvey et al. 1992 \\
\hline 1.5-mile run (Mi/min) & FBI Agents & 223.6 & 200.6 & $90 \%$ & 2551M:649W & Knapik et al. 2011b \\
\hline $\begin{array}{l}1.5 \text { Mile Run } \\
\text { (Mi/min) }\end{array}$ & Special Agents & 199.4 & 176.1 & $88 \%$ & $145 \mathrm{M}: 46 \mathrm{~W}$ & Gebhardt et al. 2012 \\
\hline $\begin{array}{l}1.5 \text { Mile Run } \\
\text { (Mi/min) }\end{array}$ & Customs Officers & $176.7^{*}$ & 146.0 & $83 \%$ & $86 \mathrm{M}: 47 \mathrm{~W}$ & O'Leary et al. 2009 \\
\hline 2 mile Run (Mi/min) & US Soldiers & 213.2 & 175.9 & $83 \%$ & 5346M:676W & Knapik et al, 1994 \\
\hline $1-2$ mile run $(\mathrm{m} / \mathrm{sec})$ & $\begin{array}{l}\text { Outdoor telephone crafters, } \\
\text { Law Enforcement, Soldiers }\end{array}$ & 218.2 & 189.3 & $\begin{array}{c}87 \% \\
(83 \%-99 \%)\end{array}$ & 3696M:1051W & $\begin{array}{l}\text { Arvey et al. 1992; } \\
\text { Gebhardt et al. 2012; } \\
\text { Knapik et al, 1994; } \\
\text { Knapik et al, 2011b; } \\
\text { O'Leary et al. 2009 }\end{array}$ \\
\hline \multicolumn{7}{|c|}{ Sprint and Agility Basic Fitness Component Tests } \\
\hline $91.4 \mathrm{~m}$ sprint (sec) & Outdoor telephone crafters & 13.9 & 15.3 & $91 \%$ & 96M:19W & Arvey et al. 1992 \\
\hline 300-m sprint (sec) & FBI Agents & $45.3^{*}$ & 54.9 & $73 \%$ & 2578M:654W & Knapik et al. 2011b \\
\hline 300-m sprint (sec) & American Soldiers & $52.8^{*}$ & 63.6 & $83 \%$ & 607M:229W & Foulis et al. 2015 \\
\hline 201-m Sprint (sec) & Customs Officers & $40.9 *$ & 54.9 & $74 \%$ & $86 \mathrm{M}: 47 \mathrm{~W}$ & O'Leary et al. 2009 \\
\hline $\begin{array}{l}\text { Sprint }(\mathrm{m} / \mathrm{sec}) \\
\text { Weighted Mean }\end{array}$ & $\begin{array}{l}\text { Outdoor telephone crafters, } \\
\text { Law Enforcement, Soldiers }\end{array}$ & 6.45 & 5.22 & $\begin{array}{c}81 \% \\
(73 \%-91 \%)\end{array}$ & 3322M:962W & $\begin{array}{l}\text { Arvey et al. 1992; } \\
\text { Foulis et al. 2015; } \\
\text { Knapik et al. 2011b; } \\
\text { O'Leary et al. 2009 }\end{array}$ \\
\hline $\begin{array}{l}\text { Illinois Agility Run } \\
\text { (sec) }\end{array}$ & Special Agents & 18.5 & 20.2 & $92 \%$ & $145 \mathrm{M}: 46 \mathrm{~W}$ & Gebhardt et al. 2012 \\
\hline $\begin{array}{l}\text { Illinois Agility Run } \\
\text { (sec) }\end{array}$ & Telecommunication Workers & 19.8 & 23.3 & $85 \%$ & 191M:33W & Gebhardt et al. 1998 \\
\hline $\begin{array}{l}\text { Illinois Agility Run } \\
\text { (sec) }\end{array}$ & American Soldiers & 19.2 & 21 & $91 \%$ & $608 \mathrm{M}: 229 \mathrm{~W}$ & Foulis et al. 2015 \\
\hline $\begin{array}{l}\text { Illinois Agility Run } \\
\text { (sec) }\end{array}$ & $\begin{array}{l}\text { Special Agents, Telecom } \\
\text { Workers, American Soldiers }\end{array}$ & 19.2 & 21.1 & $\begin{array}{c}91 \% \\
(85 \%-92 \%)\end{array}$ & 944M:308W & $\begin{array}{c}\text { Foulis et al. 2015; } \\
\text { Gebhardt et al. 1998; } \\
\text { Gebhardt et al. } 2012\end{array}$ \\
\hline \multicolumn{7}{|c|}{ Sprint and Agility Job Task Simulations } \\
\hline $\begin{array}{l}\text { Pursuit \& Handcuff } \\
\text { (sec) }\end{array}$ & Special Agents & 95.5 & $120.8^{*}$ & $79 \%$ & $145 \mathrm{M}: 46 \mathrm{~W}$ & Gebhardt et al. 2012 \\
\hline $\begin{array}{l}\text { Pursuit \& handcuff } \\
\text { (remove person from } \\
\text { vehicle, chase, } \\
\text { handcuff) }\end{array}$ & Customs Officers & 77.8 & $94.6^{*}$ & $82 \%$ & $86 \mathrm{M}: 47 \mathrm{~W}$ & O'Leary et al. 2009 \\
\hline Pursuit \& Handcuff & $\begin{array}{l}\text { Special Agents, Customs } \\
\text { Officers }\end{array}$ & 88.9 & 107.6 & $83 \%$ & 231M:93W & $\begin{array}{l}\text { Gebhardt et al. 2012; } \\
\text { O'Leary et al. } 2009\end{array}$ \\
\hline
\end{tabular}

$\mathrm{M}=$ male, $\mathrm{W}=$ female, $\mathrm{FBI}=$ Federal Bureau of Investigation, $\mathrm{US}=$ United States, $\mathrm{VO}_{2} \mathrm{max}=$ maximal

oxygen consumption, $\mathrm{VO}_{2}$ submax $=$ submaximal oxygen consumption, $\mathrm{ml} / \mathrm{kg} / \mathrm{min}=$

milliliter/kilogram $/$ minute, $\mathrm{Mi} / \mathrm{min}=$ miles $/$ minute, $\mathrm{sec}=$ second, $\mathrm{m}=$ meters . 
*Significantly better performance when reported.

${ }^{\wedge} \mathrm{VO}_{2} \mathrm{max}$ estimated from submaximal cycle test.

${ }^{\#} \mathrm{VO}_{2}$ at the Ventilatory Threshold. 
Figure 1. Frequency distribution of $38 \mathrm{~cm}$ upright pull isometric lifting strength of men $(n=1002)$ and women ( $n=998)$ A). A subject using the device B). Absolute strength $(\mathrm{kg})$ and C). Strength divided by fat free mass (modified with permission from Sharp, 1994). 

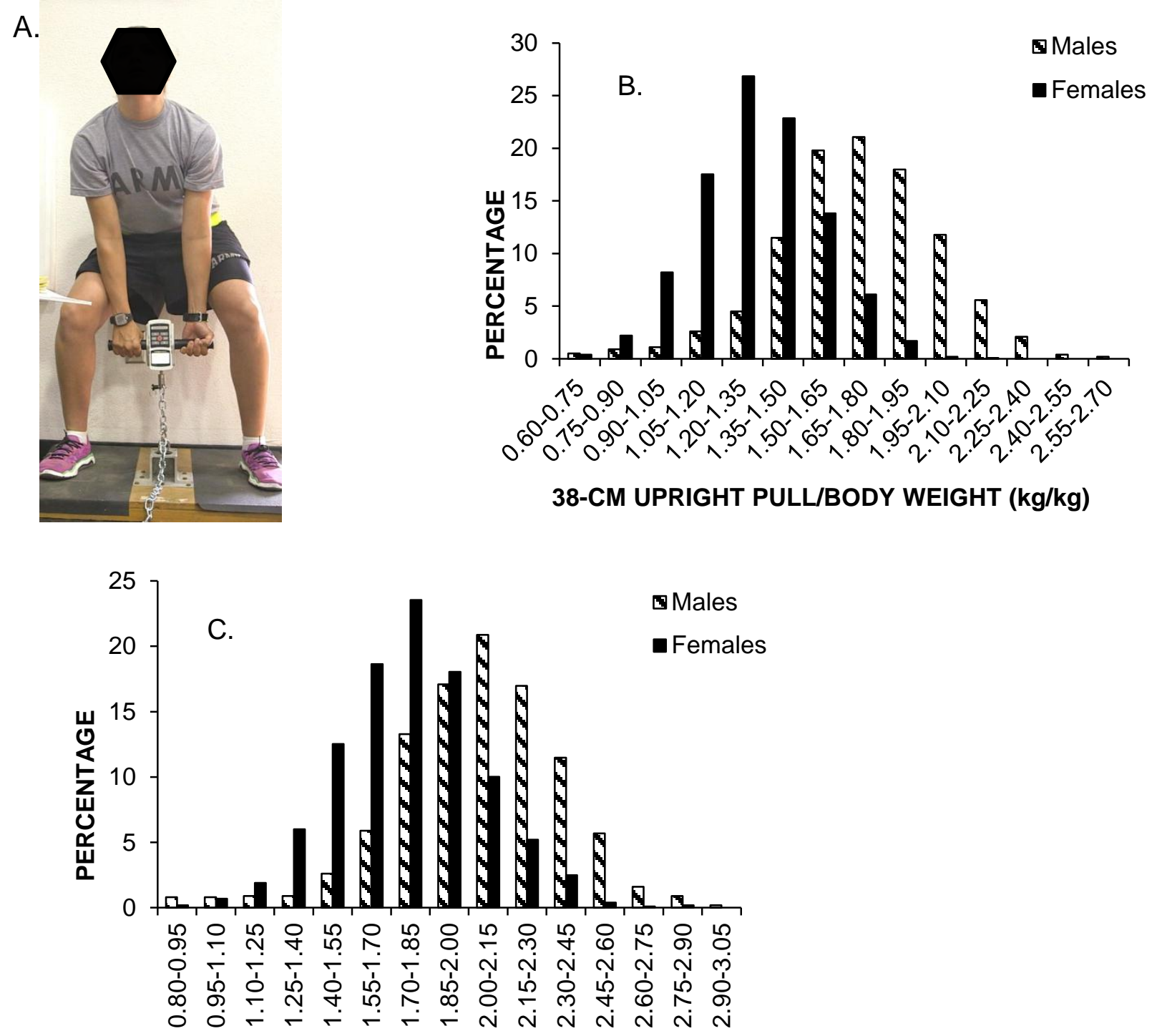

38-CM UPRIGHT PULL/FAT FREE MASS $(\mathrm{kg} / \mathrm{kg})$ 